\title{
Evaluation of bio-detoxification of Jatropha curcas seed cake and cottonseed cake by basidiomycetes: nutritional and antioxidant effects
}

Marina Borges Guimarães ( $\nabla$ marinaborgesguimaraes@gmail.com )

UnB: Universidade de Brasilia https://orcid.org/0000-0002-8767-407X

Félix Gonçalves de Siqueira

Embrapa Agroenergia

Raquel Bombarda Campanha

Embrapa Agroenergia

José Antônio de Aquino Ribeiro

Embrapa Agroenergia

Pérola Oliveira Magalhães Dias Batista

UnB: Universidade de Brasilia

Simone Mendonça

Embrapa Agroenergia

\section{Research Article}

Keywords: macauba cake, coconut husks, bio-detoxification, antioxidant activity, basidiomycetes

Posted Date: June 9th, 2021

DOI: https://doi.org/10.21203/rs.3.rs-421819/v1

License: (c) (1) This work is licensed under a Creative Commons Attribution 4.0 International License.

Read Full License

Version of Record: A version of this preprint was published at Waste and Biomass Valorization on October 22nd, 2021. See the published version at https://doi.org/10.1007/s12649-021-01599-4. 


\section{Abstract}

Poultry and swine are the major proportion of the livestock industry in terms of output value. To meet the growing need for protein sources in these sectors, the use of biomasses coming from agro-industrial residues can be an interesting option in the coming years. This study aimed to evaluate the capacity of seven basidiomycetes to grow, detoxicate, increase protein content, and also its antioxidant activity when grew in pure Jatropha seed cake (JSC) and cottonseed cake (CSC) biomasses and mixtures containing $50 \%$ of lignocellulosic biomasses from coconut husks and Acrocomia aculeata (macauba cake). Results showed that five basidiomycetes were able to grow in these substrates. F. hepatica, P. lecomtei, and $P$. pulmonarius presented the highest bio-detoxification capacity. All treatments showed a reduction in total phenolic compounds (TPC) and antioxidant activity, but treatments with coconut husks showed lower reductions. Results also indicated that there are molecules produced by basidiomycetes responsible for antioxidant activity other than phenolic compounds. These results indicated that basidiomycetes could detoxify JCS and CSC biomasses, suggesting their possible use in animal feed and that the addition of coconut husks in JSC and macauba cake in cottonseed cake can promote greater colonization by fungi.

\section{Statement Of Novelty}

Globally, there is an increasing demand for sustainable protein sources for animal feed. The use of agroindustrial wastes appears as a viable, economic and ecological alternative. In this context biomasses from Jatropha curcas seed cake (JSC), cottonseed cake (CSC). However, JSC and CSC contain toxic compounds that can impair animals' digestibility. Bio-detoxification with macro-fungi is a cheap and efficient process to reduce the concentration of these substances and improve protein content, besides generating edible mushrooms and lignocellulosic enzymes. Our work evaluated the colonization of seven different basidiomycetes in pure and mixed biomasses with lignocellulosic agro-industrial wastes aiming to select a suitable one for animal feed, focusing on reducing producer's cost and avoiding environmental disposal.

\section{Introduction}

As the human population grows, the demand for food increases proportionately. To help address the global food challenge, researchers have developed alternatives sources of animal feed for poultry and swine industries, the most consumed meats in the world. Among these new options for animal consumption, oil press cakes have been widely used as sources of proteins and carbohydrates.

Amongst the biomasses with potential for use in animal nutrition, Jatropha curcas seed cake and cottonseed cake, residues of oil extraction, both oilseeds suitable for biodiesel production, are good candidates especially due to their high protein content. However, toxic compounds such as phorbol esters and free gossypol, present respectively in Jatropha cake and cottonseed cake, make these materials unsafe for animal feed. Phorbol esters can act either acutely inducing an intense inflammatory response, or chronically, inducing tumor development [1]. Free gossypol (FG) can cause infertility and toxicity in 
young ruminants and monogastric animals [2]. As an alternative to enable the use of these biomasses, colonization with macrofungi (basidiomycetes) offers the advantages of being a low-cost process to biodetoxicate these substrates and also the production of value-added products, such as edible mushrooms and lignocellulosic enzymes [3]. Besides, the cultivation of mushrooms in agro-industrial wastes can improve their protein content, produce bioactive molecules such as phenolic compounds, polysaccharides, sterols, and reduce lignin and cellulose content, improving their digestibility for animal feed [4]. A good balance of carbon-nitrogen is important to promote the better growth of fungi [5]. So, the combination of Jatropha or cottonseed cakes as protein sources, and coconut husks or Acrocomia aculeata (Jacq.) Lodd. ex Mart. (palm) cakes as carbohydrates source, is interesting for basidiomycetes cultivation as well since the last ones make the carbon-nitrogen balance increases. Finally, carotenoids of Acrocomia aculeata and the high phenolic content of coconut husks might help the antioxidant activity of final biomasses products [6].

Basidiomycetes are a class of fungi with species that produce visible fruiting bodies commonly known as mushrooms [7]. They have high commercial value due to their nutritional composition and for being an alternative source of quality proteins and essential amino acids $[8,9]$ as well as because some species present medicinal properties. Among basidiomycetes used for bio-detoxification purposes, some species stand out. Agaricus subrufescens (syn. A. blazei, A. brasiliensis), also known in Brazil as "Sun mushroom" is widely consumed for its medicinal activities [10] being known for preventing a range of diseases such as cancer, diabetes, arteriosclerosis, and others [11]. Lentinula edodes is popularly known as Shiitake and it is the second most-consumed mushroom in the world. Shiitake has high nutritional value and medicinal properties, being pointed as a good choice to reduce cholesterol, modulation of the immune system, and by its anti-inflammatory properties [12]. Schyzophyllum commune is one of the most common mushrooms in nature. Although usually classified as a non-edible species due to its fibrous texture, it is consumed traditionally in Mexico [13]. S. commune gained pharmaceutical visibility after the discovery of its derived polysaccharide, schizophyllan, which has anticancer activity [14].

Another species of basidiomycetes applied in bio-detoxication is Pleurotus spp. popularly known as oyster mushroom. $P$. ostreatus is widely consumed, while $P$. eryngii and $P$. pulmonarius are less consumed. These two species present, however, anticancer, anti-inflammatory, and antimicrobial properties already recognized mainly for their polysaccharides, peptides, proteins, triterpenes, and nucleotides [15]. Fistulina hepatica is another basidiomycete known for its medicinal properties. Its antimicrobial and antioxidant activities have already been studied and polysaccharides and phenolic compounds have been identified as bioactive molecules $[16,17]$. Panus lecomtei is a mushroom traditionally consumed in Brazilian indigenous communities and Japan. Little is known about this species, however, some authors $[18,19]$ have already reported that $P$. lecomtei has anticancer and antimicrobial activities. Finally, Ganoderma lucidum also called Reishi mushroom, the "immortality mushroom", has traditionally been used in Chinese medicine to prevent hepatitis, nephritis, hypertension, and asthma, and also to stimulate the immune system [20]. The bioactive compounds identified in $G$. lucidum include triterpenoids, polysaccharides, nucleotides, sterols, and proteins; being these molecules responsible for anticancer, antimicrobial, anti-inflammatory, antioxidant, antifungal, and anti-viral 
properties of the species [21]. Nowadays, global concern about antibiotic resistance and residues in animal products has resulted in the search for alternatives to growth promoters and veterinary drugs (such as prebiotics, probiotics, and other feed additives), focus on reducing the use of antimicrobials in animal production [22].

Therefore, this work aimed to evaluate growing, detoxicating efficiency, protein gain, and improvement of antioxidant activity of four basidiomycetes with medicinal properties (Agaricus subrufescens, Schyzophyllum commune, Fistulina hepatica, and Ganoderma lucidum), and three edible mushrooms (Lentinula edodes, Pleurotus spp, and Panus lecomtei) cultivated in pure biomasses of Jatropha curcas seed cake and cotton seed cake and combined with coconut husks and macauba cake biomasses. Results obtained here can be used in poultry and swine industries as a guide to select biomasses suitable for animal feed enriched with bioactive compounds, reducing meat-producing costs, and avoiding the disposal of these agro-residues in the environment.

\section{Materials And Methods \\ 2.1 Plant Material}

Four different biomasses for basidiomycetes growth were used in this experiment: pure Jatropha seed cake (JSC) and cottonseed cake (CSC) and in mixtures containing 50\% of lignocellulosic biomasses from coconut husks (CH) and Acronomia aculeata (macauba cake-MC). Seeds from Jatropha curcas were provided by Embrapa Cerrados (Planaltina - DF, Brazil). After mechanically extract the oil, the cake was dried for $30 \mathrm{~min}$, at $100^{\circ} \mathrm{C}$, in rotatory dryer. Cottonseed cake was provided by Farmotec Industry (Buritis - MG, Brazil).

Coconuts husks were obtained from local sellers (Brasília - DF, Brazil), crushed, and subsequently ovendried for 1 week, at $60^{\circ} \mathrm{C}$. Macauba (Acronomia aculeata) fruits were provided by Agrotech/Soleá Company (João Pinheiro - MG, Brazil). Macauba mesocarp had its oil extracted mechanically, and residual solid biomass was dried for $30 \mathrm{~min}$, at $100^{\circ} \mathrm{C}$.

\subsection{Media preparation and basidiomycetes cultivation}

Fungi tested were Agaricus subrufescens (strain CC414), Lentinula edodes, Schizophyllum commune (strain FPB117), Pleurotus pulmonarius (strain EF88), Fistulina hepatica (strain CC102), Panus lecomtei (strain CC40), and Ganoderma lucidum (strain CC351). Samples were obtained from the Microorganisms and Microalgae Collection (Coleção de Microrganismos e Microalgas Aplicados Bioferrefinaria CMMABio) from Embrapa Agroenergy (Brasília - DF, Brazil). Strains were preserved in potato dextrose agar plates (PDA) at $4^{\circ} \mathrm{C}$. The inoculum was prepared by transferring disks of $5 \mathrm{~mm}$ of diameter from the preserved cultures to another PDA plate, and incubating it in a BOD incubator, for 7 days, at $28^{\circ} \mathrm{C}$.

Growth medium assayed were pure Jatropha seed cake (JSC) and cottonseed cake (CSC), Jatropha seed cake with coconut husks $(\mathrm{JSC}+\mathrm{CH})$, cottonseed cake with coconut husks $(\mathrm{CSC}+\mathrm{CH})$, Jatropha seed cake 
with macauba cake (JSC+MC), and cottonseed cake with macauba cake (CSC+MC). In each $10 \mathrm{~cm}$ jar ( $225 \mathrm{ml}$ of volume), $15 \mathrm{~g}$ of each biomass was weighted, totaling $30 \mathrm{~g}$ for mixtures. For JSC and CSC puree, $30 \mathrm{~g}$ were added to each jar. Biomasses humidity was adjusted to approximately $65 \%$ by adding water and sterilized in an autoclave for $45 \mathrm{~min}$, at $121^{\circ} \mathrm{C}$. After cooling, 4 disks ( $5 \mathrm{~mm}$ of diameter) of each basidiomycete's inoculum were added to each jar. Also, jars without inoculum were incubated at the same conditions as uncolonized control samples. Cultures were prepared in triplicate. Jars were incubated for 15 days at $28^{\circ} \mathrm{C}$, in a BOD incubator. After incubation time, cultures were dried with air circulation for $48 \mathrm{~h}$, at $40^{\circ} \mathrm{C}$, milled, and stored at $-20^{\circ} \mathrm{C}$ until further analysis.

\subsection{Growth rate}

During the 15 days of incubation time, every 3 days, mycelium growth was measured. At the end of the cultivation period, the growth rate for each fungus at each different biomass was estimated in $\mathrm{cm} /$ day. Basidiomycetes incapable of growing in the biomasses assayed were excluded from further analysis.

\subsection{Phorbol ester and free gossypol quantification}

Phorbol ester quantification in JSC was performed in triplicate. The applied method was adapted from the original protocol described in the literature [23]. Thus, $15 \mathrm{~mL}$ of methanol was added to falcon tubes containing $3 \mathrm{~g}$ of cultures grown with jatropha seed cake and then crushed with Teflon sticks for 1 min. After that, they were ultrasonicated (USC480A, Unique, SP, Brazil) at an ice bath, for $3 \mathrm{~min}$. Tubes were centrifuged at $9000 \mathrm{rpm}$, for $8 \mathrm{~min}$, and the supernatant was transferred to a round bottom flask and was evaporated in a rotary evaporator under vacuum (Rotavapor R210/215, Büchi Labortechnik, Flawil, Swiss), at $40^{\circ} \mathrm{C}$. Phorbol esters were resuspended with $5 \mathrm{~mL}$ of methanol and centrifuged at $14000 \mathrm{rpm}$, for $8 \mathrm{~min}$, at $8^{\circ} \mathrm{C}$. Chromatographic analysis was performed at a UPLC (Ultra-Performance Liquid Chromatography) System (Acquity UPLC H-Class System, Waters, Massachusetts, USA) with a PDA detector, using a reverse-phase column (Waters, Acquity UPLC HSS-T3), pre-column (VanGuard HSS-T3) at $45^{\circ} \mathrm{C}$. An elution gradient was used, and the detector was adjusted at $280 \mathrm{~nm}$. A calibration curve was performed with a standard solution of phorbol myristate acetate (PMA) (Sigma-Aldrich) and results of the samples plotted on this curve to obtain phorbol esters content.

FG quantification was performed according to a method described in the literature [24]. In a falcon tube, 1 $\mathrm{g}$ of milled and dried samples was added. The extraction was performed with two sequential steps in a cold ultrasonic bath: the first one with $3 \mathrm{~mL}$ of ultrapure water and the second one with $7 \mathrm{~mL}$ of acetone. The tubes were centrifuged at $9.000 \mathrm{rpm}$, for $5 \mathrm{~min}$, at $8^{\circ} \mathrm{C}$, and finally, $1 \mathrm{~mL}$ of supernatant was transferred to $2 \mathrm{~mL}$ sample vials. The chromatography analysis was conducted on a Water Acquity UPLC $\mathrm{H}$-Class system (Waters, Milford, USA) with a PDA detector using a reverse-phase column C18 (100 x 2.1 $\mathrm{mm}, 2.6 \mu \mathrm{m}, \mathrm{KINETEX} \circledast$ ). A calibration curve was performed with a standard solution of gossypol ( $\geq 95 \%$ purity HPLC, Sigma-Aldrich) and results of the samples plotted on this curve to obtain free gossypol content. 
The degradation rate of both phorbol ester and free gossypol was obtained considering $100 \%$ the amount of these toxic compounds in the uncolonized biomasses.

\subsection{Ergosterol content}

Ergosterol, a primary sterol present in cell membranes of filamentous fungi is widely used to estimate fungal biomass [25]. Ergosterol quantification was performed in triplicate, applying a method adapted from a published protocol [26]. Briefly, $10 \mathrm{~mL}$ of methanol and $5 \mathrm{~mL}$ of ethanol were added to $400 \mathrm{mg}$ of dried milled culture with $2 \mathrm{~g}$ of $\mathrm{KOH}$ in assay tubes. Saponification was carried out in a water bath at $70^{\circ} \mathrm{C}$, for $30 \mathrm{~min}$. After cooling of samples, $5 \mathrm{~mL}$ of water and $10 \mathrm{~mL}$ of hexane were added. Tubes were ultrasonicated (USC480A, Unique, SP, Brazil) for $1 \mathrm{~min}$ and supernatants were collected. Extraction was performed twice using $5 \mathrm{~mL}$ of hexane each time. Extracts were pooled and rota-evaporated (Multivapor Büchi, Flawil, Swiss) with bath temperature of $40^{\circ} \mathrm{C}$. Extracts were resuspended in methanol and centrifuged at $13500 \mathrm{rpm}$, for $5 \mathrm{~min}$. Quantification was performed by injection of extracts in a UPLC system (Acquity UPLC H-Class System, Waters, Massachusetts, USA) with a PDA detector and a $2.6 \mu \mathrm{m}$ C18 column (Kinetex, Torrance, CA, USA). A calibration curve was made with an ergosterol standard (Sigma-Aldrich) and results of the samples plotted on this curve to obtain ergosterol content.

\subsection{Crude protein content}

Two mg of milled and dried colonized biomasses were weighted in a Perkin Elmer AD-6 Auto Balance (Massachusetts, EUA) and nitrogen content was quantified with a CHN (Carbon, Hydrogen and, Nitrogen) analyser (2400 CHNS/O Series II, PerkinElmer, Massachusetts, EUA). Helium was used as carrier gas. Acetanilide ( $\mathrm{C}=71.09 \%, \mathrm{~N}=10.36 \%, \mathrm{H}=6.71 \%$ ) was used to calibrate the instrument. For crude protein content, nitrogen content was multiplied by the standard default conversion factor 6.25 . This analysis was performed in triplicate [27].

\subsection{Preparation of extracts}

To carry out analyses of antioxidant properties, it was necessary to produce extracts of samples. Extracts of milled and dried colonized biomasses were obtained in triplicate, as reported below to each sample, $80 \%$ ethanol was added ( $1: 20 \mathrm{w} / \mathrm{v})$, and the solutions were placed in an ultrasonic bath (room temperature) (USC480A, Unique, SP, Brazil) for $20 \mathrm{~min}$. After that, samples were shaken at $180 \mathrm{rpm}$, for 30 $\mathrm{min}$, and finally centrifuged at $4000 \mathrm{rpm}$, for $10 \mathrm{~min}$. Then, the supernatant was collected, filtered with Whatman no. 41 filter paper, and evaporated (Rotavapor R210/215, Büchi Labortechnik, Flawil, Swiss) with bath temperature of $40^{\circ} \mathrm{C}$. Residual extracts were freeze-dried (K120, Liotop, São Carlos, SP, Brazil) and stored at $-20^{\circ} \mathrm{C}$ in the dark, until analyses.

\subsection{Antioxidant activity}

Antioxidant activity was evaluated in extracts resuspended with methanol $(5 \mathrm{mg} / \mathrm{mL})$ by two different methods of free radical scavenging activity, one with radical DPPHO (2,2-difenil-1-picrilhidrazyl) and the other with ABTS+• (2,2'-azino-bis 3-etilbenzotiazolyn-6-sulfonate) radical. 
DPPH radical antioxidant activity was performed as described by previous authors [28], with modifications. To carry out the reaction, $22 \mu \mathrm{L}$ of extract were added to a $200 \mu \mathrm{L}$ of DPPH solution (150 $\mu \mathrm{M}$ ) The absorbance of the samples was read at $520 \mathrm{~nm}$ (Molecular Devices, Spectramax 190, California, USA). Results of the samples were plotted on a calibration curve performed with Trolox (6-hidroxi-2,5,7,8tetrametilchroman-2-carboxilic acid) at $0.5 \mathrm{mg} / \mathrm{mL}$.

To analyze ABTS+・ antioxidant activity, a method described by previous authors [29] and adapted by others [30] was applied. ABTS+• solution was prepared by adding $88 \mu \mathrm{L}$ of potassium persulfate solution $(140 \mathrm{mM})$ to $5 \mathrm{~mL}$ of ABTS solution $(7 \mathrm{mM})$, kept overnight in the dark. This solution was diluted in methanol (approximately 1:40 v/v) till the absorbance at $734 \mathrm{~nm}$ reached $0.70 .10 \mu \mathrm{L}$ of the extract was added to $290 \mu \mathrm{L}$ of ABTS+・ solution and incubated at $30^{\circ} \mathrm{C}$, for $6 \mathrm{~min}$, in the dark. The absorbance of the samples was read at $734 \mathrm{~nm}$ (Molecular Devices, Spectramax 190, California, USA). Results of the samples were plotted on a calibration curve, performed with Trolox (6-hidroxi-2,5,7,8-tetrametilchroman-2carboxilic acid) at $0.5 \mathrm{mg} / \mathrm{mL}$, to obtain antioxidant activity.

\subsection{Total phenolic compounds (TPC)}

To carry out total phenolic compounds quantification, the method was adapted from a published protocol [31]. Extracts were resuspended with ethanol $80 \%(3 \mathrm{mg} / \mathrm{mL})$. Thus, $500 \mu \mathrm{L}$ of Folin-Ciocalteau (FC) reagent were added to $100 \mu \mathrm{L}$ of extract diluted in $7 \mathrm{~mL}$ of distilled water. Samples were vortexed and incubated for $8 \mathrm{~min}$, at room temperature. Then, $1.5 \mathrm{~mL}$ of $\mathrm{Na}_{2} \mathrm{CO}_{3} 20 \%(\mathrm{w} / \mathrm{v}), 900 \mu \mathrm{L}$ of water were added to the tubes, and incubated for $2 \mathrm{~h}$, at room temperature, in the dark. Sample's absorbance was read at $765 \mathrm{~nm}$ in $1 \mathrm{~mm}$ cuvettes (Agilent, Cary 60, California, USA). To obtain TPC content, the results of the samples were plotted on a calibration curve performed with Gallic Acid $(0.5 \mathrm{mg} / \mathrm{mL})$.

\subsection{Statistics}

All essays were performed in triplicate. The data were submitted to analysis of variance (ANOVA). In the case of $p<0.05$, the data were submitted to the Tukey test. Statistics analyses were performed using RStudio software [32] and graphs were made using GraphPrism 8 (GraphPad Software, La Jolla, California, EUA). Pearson's correlation test was performed grouping in one block all experiments with JCS and another with all experiments with CSC $(p<0.01)$. Analytic Hierarchy Process (AHP) was used to rank the most promising treatments.

\section{Results}

\subsection{Growth rate in Jatropha seed cake (JSC), and cottonseed cake (CSC)}

The results of the growth rate (GR) showed that of the 7 selected basidiomycetes, $A$. subrufescens and, $L$. edodes were not able to grow in the jars with biomasses containing Jatropha seed cake (JSC), Jatropha seed cake with coconut husks $(\mathrm{JSC}+\mathrm{CH})$, and Jatropha seed cake with macauba cake (JSC+MC) (Figure 1). For substrates containing cottonseed cake (CSC), cottonseed cake with coconut husks $(\mathrm{CSC}+\mathrm{CH})$, and 
cottonseed cake with macauba cake (CSC+MC), A. subrufescens was also unable to grow, while $L$. edodes showed a very low growth rate (Figure 2). Considering the inability of both species $(A$. subrufescens and $L$. edodes) to grow in the tested substrates, they were excluded from further analysis.

All the other basidiomycetes species (S. commune, P. pulmonarius, F. hepatica, P. lecomtei, and G. lucidum) were capable to grow completely in jars for 15 days. P. lecomtei and $S$. commune presented the highest growth rate in Jatropha seed cake (JSC) (Figure 1a) and cottonseed cake (CSC) (Figure 2a) respectively, showing GR of 0.66 and $0.69 \mathrm{~cm} /$ day. These two species also showed higher GR in JSC+MC (Figure 1c) and CSC+MC (Figure 2c), differing statically from the other 5 basidiomycetes species.

As for substrates containing coconut husks $(\mathrm{CH})$, in $\mathrm{JSC}+\mathrm{CH}, \mathrm{S}$. commune, F. hepatica, and P. lecomtei presented the highest growth rate $(0.56,0.51$, and $0.46 \mathrm{~cm} /$ day, respectively), statically differing from the other tested species (Figure 1b). In CSC+MC, diverse growth rates were obtained (Figure 2b) with $P$. lecomtei and $S$. commune presenting higher GR $(0.59$ and $0.58 \mathrm{~cm} /$ day, respectively), followed by $F$. hepatica $(0.34 \mathrm{~cm} /$ day) .

\subsection{Phorbol ester, gossypol, ergosterol, and crude protein contents}

\subsubsection{Jatropha seed cake (JSC)}

Results of phorbol ester content in JSC showed the that control sample (uncolonized) presented 1.16 $\mathrm{mg} / \mathrm{g}$ of phorbol ester, while mixtures of $\mathrm{JSC}+\mathrm{CH}$ and $\mathrm{JSC}+\mathrm{MC}$ presented $0.42 \mathrm{mg} / \mathrm{g}$ and $0.47 \mathrm{mg} / \mathrm{g}$, respectively. Colonized samples presented phorbol ester contents in JSC varying from the lowest value of $0.02 \mathrm{mg} / \mathrm{g}$, to the highest amount of $0.19 \mathrm{mg} / \mathrm{g}$, identified in $P$. lecomtei and $S$. commune colonization, respectively. In $\mathrm{JSC}+\mathrm{CH}$ colonized samples, phorbol ester values varied from $0.02 \mathrm{mg} / \mathrm{g}$ of $P$. lecomtei and $P$. pulmonarius to $0.24 \mathrm{mg} / \mathrm{g}$ for $G$. lucidum colonization. In JSC+MC, values varied from $0.01 \mathrm{mg} / \mathrm{g}$ for $P$. lecomtei and $P$. pulmonarius, and $0.06 \mathrm{mg} / \mathrm{g}$ for $S$. commune and $F$. hepatica colonization (Table 1). Finally, in colonized JSC substrates degradation percentage ranged from $53.8 \%$ for $G$. Iucidum (JSC+CH) to $98.2 \%$ for $P$. lecomtei (JSC) (Table 1 ).

Ergosterol content analysis in uncolonized biomasses of $\mathrm{JSC}, \mathrm{JSC}+\mathrm{CH}$, and $\mathrm{JSC}+\mathrm{MC}$ showed contents of $52.5,40.9$, and $35.5 \mathrm{ppm}$, respectively. Meanwhile, in colonized materials, ergosterol was quantified in contents up to $1268.7 \mathrm{ppm}$ (JSC+MC) and $1261.4 \mathrm{ppm}(\mathrm{JSC}+\mathrm{CH})$ for $S$. commune, followed by colonization of $P$. pulmonarius in $\mathrm{JSC}+\mathrm{CH}(763.1 \mathrm{ppm})$ and JSC+MC $(694.1 \mathrm{ppm})$ biomasses. Overall, for all other species, JSC biomass containing $\mathrm{CH}$ presented higher ergosterol content when compared to JSC, and JSC+MC (Table 1).

Since $\mathrm{CH}$ and $\mathrm{MC}$ are biomasses lower in protein content, higher crude protein content was identified in uncolonized pure JSC biomass than in the mixtures. Uncolonized biomasses mixtures presented different protein contents: $27.9 \mathrm{~g} / 100 \mathrm{~g}$ in JSC, $11.4 \mathrm{~g} / 100 \mathrm{~g}$ in JSC+CH, and $16.9 \mathrm{~g} / 100 \mathrm{~g}$ in JSC+MC. Usually, the protein content of cultivation medium increases because of syntheses of fungal protein and also due to consumption of lignocelulitic material during growth, leading to an effect of protein concentration due to 
depletion of other components. The crude protein content of colonized JSC biomass ranged from 20.8 $\mathrm{g} / 100 \mathrm{~g}$ for $P$. pulmonarius to $30.1 \mathrm{~g} / 100 \mathrm{~g}$ for $G$. lucidum. For JSC mixed coconut husks $(\mathrm{CH})$, crude protein content varied from $17.3 \mathrm{~g} / 100 \mathrm{~g}$ for $S$. commune to $19.7 \mathrm{~g} / 100 \mathrm{~g}$ for $F$. hepatica. For JSC+MC, CP data ranged from $18.7 \mathrm{~g} / 100 \mathrm{~g}$ for $P$. pulmonarius to $22.5 \mathrm{~g} / 100 \mathrm{~g}$ for $F$. hepatica (Table 1 ).

Although presenting average ergosterol content, which is an indicator of fungi growth, $P$. pulmonarius and S. commune species were not capable to concentrate protein by bioconversion in pure JSC, showing decreases in protein content of colonized biomass, -16.9 and $-25.7 \%$, respectively (Table 1 ). The coefficient $r$ of Pearson between initial protein content and \% of increase of protein was inversely proportional $(r=-0,88 ; P<0.01)$. For all other species, lower conversions were identified in JSC, being 1.2, 7.6 and, $7.8 \%$, respectively for P. lecomtei, F. hepatica, and G. Iucidum. Higher protein bioconversion was identified in $\mathrm{JSC}+\mathrm{CH}$ biomass. Although there was no statistical difference between fungi treatments, an increase of $72.0 \%$ was identified for $F$. hepatica colonization, followed by an increase of $66.5 \%$ for $G$. lucidum, $56.6 \%$ for P. pulmonarius, $51.5 \%$ for $S$. commune, and $47.5 \%$ for $P$. lecomtei (Table 1 ). In JSC+MC biomass, the most notable increase was $33.7 \%$ in $F$. hepatica colonized material, while $P$. pulmonarius showed the smallest increase (10.8\%).

\subsubsection{Cottonseed cake (CSC)}

Results of FG content in uncolonized biomasses varied between 2170.8 ppm (CSC), and $607.2 \mathrm{ppm}$ (CSC+MC). In colonized biomasses, FG content varied from $59.4 \mathrm{ppm}$ for $P$. pulmonarius to $423.0 \mathrm{ppm}$ for $S$. commune colonization in CSC. In CSC+CH, FG content ranged from $90.56 \mathrm{ppm}$ with $F$. hepatica colonization to $658.4 \mathrm{ppm}$ with $S$. commune colonization. In CSC+MC samples, FG content varied from $3.5 \mathrm{ppm}$ for $P$. lecomtei colonization, to $454.6 \mathrm{ppm}$ with $S$. commune (Table 2).

Higher percentages of FG degradation were identified in CSC+MC biomass for P. lecomtei, F. hepatica, and $G$. Iucidum colonization with percentages of $99.4,98.9$, and $93.9 \%$, respectively. While $F$. hepatica and $P$. lecomtei showed higher degradation in $\mathrm{CSC}+\mathrm{CH}$ (88.5 and $87.1 \%$, respectively). The lowest percentages of FG degradation were $16.5 \%$ for $S$. commune growing in $\mathrm{CSC}+\mathrm{CH}$ and $25.5 \%$ in CSC+MC (Table 2).

Ergosterol content in uncolonized biomasses were $47.3,37.7$, and $51.7 \mathrm{ppm}$ respectively at CSC, $\mathrm{CSC}+\mathrm{CH}$, and CSC+MC. In colonized material is expected the ergosterol content increases since it is a primary sterol present in the cell membranes of filamentous fungi and has been used as a biomarker of fungi growth. The highest ergosterol content was $2.321 \mathrm{ppm}$, identified for $S$. commune at CSC+MC, in agreement with the visual growth rate observed in this specific experiment. In CSC biomass treated with fungi, ergosterol content varied between 621.7 for $F$. hepatica to $1.665 .6 \mathrm{ppm}$ for $S$. commune. For $\mathrm{CSC}+\mathrm{CH}$ fungi treatments, ergosterol content varied from $676.7-1291.0 \mathrm{ppm}$, for $F$. hepatica and $P$. lecomtei, respectively. For CSC+MC fungi treatments, ergosterol content ranged from 769.6 to 2.321,0 ppm identified respectively, for $P$. lecomtei and $S$. commune (Table 2).

Overall, higher protein contents were identified in pure CSC, followed by $\mathrm{CSC}+\mathrm{MC}$ and $\mathrm{CSC}+\mathrm{CH}$ biomasses. Protein contents for uncolonized treatment were $27.6 \mathrm{~g} / 100 \mathrm{~g}, 12.3 \mathrm{~g} / 100 \mathrm{~g}$ and, $15.1 \mathrm{~g} / 100 \mathrm{~g}$ 
respectively for $\mathrm{CSC}, \mathrm{CSC}+\mathrm{CH}$, and $\mathrm{CSC}+\mathrm{MC}$ biomasses mixtures. The protein content of fungi treated CSC varied from $30.4 \mathrm{~g} / 100 \mathrm{~g}$ for $P$. pulmonarius to $32.4 \mathrm{~g} / 100 \mathrm{~g}$ for $F$. hepatica. In the CSC+CH biomass mixture, protein content ranged from $14.0 \mathrm{~g} / 100$ to $16.8 \mathrm{~g} / 100 \mathrm{~g}$, respectively for G. lucidum and $S$. commune. Finally, in CSC+MC biomass, protein content varied from $18.8 \mathrm{~g} / 100 \mathrm{~g}$ to $21.9 \mathrm{~g} / 100 \mathrm{~g}$ for $P$. pulmonarius and $F$. hepatica, respectively (Table 2).

The highest protein bioconversions were identified for $F$. hepatica and $P$. lecomtei at CSC+MC, 44.7 and $41.6 \%$, respectively; followed by $S$. commune and $P$. pulmonarius at $\mathrm{CSC}+\mathrm{CH}, 36.5$ and $36 \%$, respectively. Lower protein conversions were identified in CSC+MC biomass for G. Iucidum and P. pulmonarius, 7.7 and $10.8 \%$, respectively (Table 2 ).

The highest increments were reached in $\mathrm{JSC}+\mathrm{CH}$ treated with $F$. hepatica $(72 \%)$ followed by $\mathrm{JSC}+\mathrm{CH}$ with G. Iucidum (66.6\%) and JSC+CH treated with P. pulmonarius (56.6\%). For CSC, best protein increments after fungi colonization were 34 and $36 \%$ in $\mathrm{JSC}+\mathrm{CH}$ treated with $P$. pulmonarius and $F$. hepatica respectively, as well in CSC+MC treated with Panus lecomtei and F. hepatica, with increments of 41.6 and $44.7 \%$, respectively.

\subsection{Antioxidant activity and phenolic compounds}

\subsubsection{Jatropha seed cake}

Results showed that antioxidant activity decreased in all treatments compared to uncolonized (control) biomasses. This could be related to oxidative enzymes produced during fungi growth. Therefore, the best treatment would be those presenting smaller losses in the ability to react with DPPH and ABTS free radicals. In DPPH• assay, TEAC from JCS colonized varied between 2.4 (which was also the lowest data among all biomasses and basidiomycetes tested) and $31.0 \mu \mathrm{g} / \mathrm{mg}$ of extract for $P$. lecomtei, and $S$. commune, respectively. In JCS+CH biomass results varied between 12.8 and $56.0 \mu \mathrm{g} / \mathrm{mg}$ (which was also the highest data among all biomasses and basidiomycetes teste) of extract, for $P$. lecomtei, and $P$. pulmonarius, respectively. In JCS+MC treatment, TEAC ranged from $15.9 \mu \mathrm{g} / \mathrm{mg}$ of extract identified for $P$. pulmonarius to $27.8 \mu \mathrm{g} / \mathrm{mg}$ of extract for $F$. hepatica (Table 3 ).

In ABTS+• assay, TEAC varied between 18.4 and $62.4 \mu \mathrm{g} / \mathrm{mg}$ of extract, for $P$. pulmonarius and $G$. lucidum, respectively in JCS treatments. In JCS $+\mathrm{CH}$ treatment, TEAC ranged from 23.2 to $97.2 \mu \mathrm{g} / \mathrm{mg}$ of extract for $P$. lecomtei and $P$. pulmonarius, respectively. P. lecomtei and G. lucidum presented respectively, 6.4 and $55.1 \mu \mathrm{g} / \mathrm{mg}$ of extract in $\mathrm{JSC}+\mathrm{MC}$, with remaining sample results falling in between these values. From all colonized biomasses in Jatropha seed cake, antioxidant activity from P. pulmonarius, in $\mathrm{JCS}+\mathrm{CH}$ treatment, presented the highest values between all other colonized biomasses, although not differing statistically to other treatments (Table 3 ).

Total phenolic compounds in uncolonized biomasses was higher in pure JCS when compared to JCS with mixtures (JSC+CH, and JSC+MC) (Table 3). TPC presented a great reduction for colonized treatments. No TPC data was detected for $P$. pulmonarius and $P$. lecomtei at this treatment. The only 
treatment that presented TPC similar to untreated materials was JCS+CH biomass with G. lucidum, with $31.8 \mu \mathrm{g}$ of $\mathrm{GAE} / \mathrm{mg}$ of extract. Phenolic compounds are usually related to antioxidant activity in plant materials, but in fungi treated biomasses this was not observed. The Pearson correlation analysis revealed that the TPC does not present correlations with DPPH• assay or with ABTS+• assay.

\subsubsection{Cottonseed cake}

In CSC fungi treated samples, TEAC by DPPH• assay varied between 4.2 to $14.1 \mu \mathrm{g} / \mathrm{mg}$ of extract, for $P$. lecomtei and S. commune, respectively. In CSC+CH treatment, TEAC ranged between 11.0 and 20.2 $\mu \mathrm{g} / \mathrm{mg}$ of extract, respectively, for $P$. pulmonarius and $F$. hepatica. For CSC+MC treatment, higher and lower TEAC were 15.4 and $18.9 \mu \mathrm{g} / \mathrm{mg}$ of extract, identified respectively for $P$. lecomtei and $F$. hepatica colonization. Overall, all treatments showed lower antioxidant activity when compared to uncolonized control (Table 4).

When TEAC was quantified in an ABTS+• assay, in CSC treatment, results varied between 15.3 and 37.2 $\mu \mathrm{g} / \mathrm{mg}$ of extract, for $P$. lecomtei and $S$. commune, respectively. In $\mathrm{CSC}+\mathrm{CH}$ treatment, TEAC varied between 24.6 and $56.6 \mu \mathrm{g} / \mathrm{mg}$ (which was also the highest data among all biomasses and basidiomycetes teste) of extract, identified, respectively, for $P$. lecomtei and G. lucidum. Finally, in CSC+MC treatment, TEAC ranged between $13.8 \mu \mathrm{g} / \mathrm{mg}$ of extract for $P$. lecomtei to $48.2 \mu \mathrm{g} / \mathrm{mg}$ of extract corresponding to $S$. commune. The highest TEAC results were obtained with $\mathrm{CSC}+\mathrm{CH}$ biomass colonized with G. Iucidum, S. commune, and F. hepatica, 56.6, 56.2, and $52.6 \mu \mathrm{g} / \mathrm{mg}$ of extract, respectively (Table 4).

Uncolonized biomasses, $\mathrm{CSC}$ and $\mathrm{CSC}+\mathrm{CH}$ presented higher $\mathrm{GAE}$ values, 21.3 and $24.3 \mu \mathrm{g}$ of $\mathrm{GAE} / \mathrm{mg}$ of extract, respectively, when compared to $\mathrm{CSC}+\mathrm{MC}$ treatment $(16.0 \mu \mathrm{g}$ of $\mathrm{GAE} / \mathrm{mg}$ of extract). Among colonized treatments, total phenolic compounds (TPC) were higher in CSC treated with G. lucidum (14.0 $\mu \mathrm{g}$ of $\mathrm{GAE} / \mathrm{mg}$ of extract), in $\mathrm{CSC}+\mathrm{CH}$ treated with for $F$. hepatica ( $14.5 \mu \mathrm{g}$ of $\mathrm{GAE} / \mathrm{mg}$ of extract), and in $\mathrm{CSC}+\mathrm{MC}$ treated with $F$. hepatica $(17.0 \mu \mathrm{g}$ of $\mathrm{GAE} / \mathrm{mg}$ of extract). For $S$. commune, P. pulmonarius, $P$. lecomtei, and G. lucidum, TPC was not detected (Table 4).

\section{Discussion}

In the current population growth scenario, demanding an increase in food, agro-industrial residues management appears as an important concern for researchers, who have developed strategies to combine the use of these residues to improve animal feed, reduce meat production costs, and prevent the disposal of this waste in the environment. Among potential residues to be applied for these purposes, Jatropha curcas cake (JSC) and cotton seedcake (CSC), both byproducts from the oil extraction industry, show interesting options, considering their high protein content. However, these biomasses present some toxic compounds that can impair animal's digestion. The application of biodegrading microorganisms capable of degrading these toxic metabolites represents a promising strategy for the elimination of these substances [1] enabling the use of these biomasses as nutritious animal feed, in addition to the potential for exploitation in the production of edible mushrooms. 
Here, we evaluated the capacity of 7 basidiomycetes species, also known as white-rot fungi, to detoxicate different protein-rich biomasses and combined with lignocellulosic ones from coconut husks $(\mathrm{CH})$ and Acronomia aculeata (macauba cake - MC). The data obtained here showed that although $A$. subrufescens and $L$. edodes were able to grow in lignocellulosic wastes, as described by some authors $[34,35]$ who reported growing in composts such as sawdust and wheat straw; these two species were not able to grow in pure JCS and CSC biomasses or combined with $\mathrm{CH}$ and MC. The cultivation of $A$. subrufescens has being described as complex, demanding $\mathrm{N}$ supplementation during all growth besides requiring strict environmental controls [36] which, may explain why no growth was achieved in the biomasses tested here. For $L$. edodes, as identified here, some authors have previously shown a remarkable growth reduction when cultivated in oak-wood sawdust, a lignocellulose-rich biomass, suggesting that nitrogen content could be a growth-limiting factor for shiitake [37, 38]. All other 5 fungi species grew in the assayed biomasses. Some authors have also reported the growth of white-rot fungi species, in pure biomasses of JSC and CSC and combined with other cellulosic sources for Pleurotus species (Oyster mushrooms), including Pleurotus pulmonarius [39, 24, 40], Schizophyllum [41], Fistulina hepatica [42], Panus lecomtei [3], and Ganoderma lucidum [43, 3].

Besides visual measurements in centimeters, another indicator of fungi colonization is the presence of ergosterol $[44,26]$. This molecule, vitamin $D_{2}$ precursor, is sterol present in cellular membranes of fungi and commonly used as an indicator of fungal growth $[45,46,25]$. Some authors have also reported higher levels of ergosterol in basidiomycetes species $[47,48,46]$, showing a positive correlation between fungi growth and ergosterol content $[47,48]$, which corroborates the use of this molecule as a fungal biomass growth indicator. It is important to highlight, however, that each fungi species has its pattern relation of growth and ergosterol content [26]. So, ergosterol is a good marker of growth to compare different biomasses or treatment approaches for the same species but showed inconsistencies to comparations among different fungi. Higher content of ergosterol was identified in colonized JSC biomass mixed with lignocellulosic material ( $\mathrm{CH}$ and $\mathrm{MC}$ ), mainly in $S$. commune, and $P$. pulmonarius. As for CSC mixed with lignocellulosic biomasses, all fungi showed higher content of ergosterol, except for $G$. lucidum. These data suggest that biomasses with lignocellulosic material induced a greater growth of the selected basidiomycetes, with coconut husks being a good additive for JSC biomass and, macauba cake for cottonseed cake; proving that a good balance of carbon-nitrogen is important to promote better growth of fungi [5]. Ergosterol is also a precursor of vitamin $\mathrm{D}_{2}$, and its presence could bring benefits to animal diet. Some authors [49] tested supplementation of $50 \mu \mathrm{g}$ mushroom vitamin D $\nabla / \mathrm{kg}$ in feed diet of pigs and found increased pork antioxidant status and improved pig growth performance, carcass weight, and color.

To be safely used in animal feed, phorbol ester and FG present, respectively, in JSC and CSC biomasses need to be destroyed. The development of a biological approach using basidiomycetes to decrease the level of toxic compounds meets fundaments of sustainable processes [4] when compared to other detoxication methods such as chemical, physical and enzymatic treatments. Usually in Jatropha seed cake levels of phorbol ester range from 1-3 mg/g, but according to some authors [1], tolerable levels of 
phorbol esters must be below $0.09 \mathrm{mg} / \mathrm{g}$ to safely be used in an animal diet. Here, levels above 0.09 $\mathrm{mg} / \mathrm{g}$ were found in S. commune in JSC, P. pulmonarius in JSC, F. hepatica in JSC $+\mathrm{CH}$, and G. lucidum in $\mathrm{JSC}$, and $\mathrm{JSC}+\mathrm{CH}$, which implies that these treatments didn't reach safe levels. Except for the treatments cited above, all treatments met levels of phorbol esters under the target threshold, reaching a high rate of detoxification, as much as $98,2 \%$ using $P$. lecomtei in pure JSC. Many authors have also reported high degradation levels of phorbol ester in biomasses colonized by basidiomycetes. It has been shown [39] a reduction of $99 \%$ in phorbol concentration, in JSC incubated for 60 days with Pleurotus ostreatus; with the same results being reported after 45-day incubation [50]. Other authors studying 10 different white-rot fungi, including three samples from Pleurotus sp. and Ganoderma lucidum, showed the degradation of PE in all tested fungi, however, the extent of degradation varied with the fungal culture [43], as observed in this work. A decrease in the concentration of phorbol esters in Ganoderma sp was also reported [4]. Authors have pointed that, the efficiency in the degradation of phorbol esters in JSC through white-rot fungi colonization could be attributed to enzymatic complexes produced during the growth process, which have high esterase activities, suggesting that phorbol ester bonds are susceptible to hydrolytic degradation [4].

As for FG content, CSC $+\mathrm{CH}$ biomass mixture showed still higher content when colonized with $S$. commune, while CSC $+\mathrm{MC}$ and $\mathrm{CSC}+\mathrm{CH}$ treated with $F$. hepatica and $P$. lecomtei, presented the lowest values, representing up to $99.4 \%$ degradation. European Union Directive 2002/32/EC limits FG in cottonseed cake feedstuffs to $20 \mathrm{ppm}$ for laying hens and piglets, $100 \mathrm{ppm}$ for poultry and calves, and $500 \mathrm{ppm}$ for cattle, goats, and sheep. So, these treated biomasses could feed even poultry. All fungi treated biomasses presented high-rate degradation (except for those with $S$. commune) reaching permissible levels for ruminant's feed. Significant reduction in FG content was also reported from other authors [24] working with Pleurotus sp., with degradation percentages reaching 100\% [51]. In addition, some authors analyzing 06 basidiomycetes including P. lecomtei, F. hepatica, Ganoderma sp., and Pleurotus sp. showed that all fungi were able to reduce FG content when colonizing CSC, with degradation percentages ranging from 74 to $94 \%$ [52]. These data corroborate the capacity of white-rot fungi to biodegrade this toxic molecule.

As a consequence of fungi fermentation, an increment in protein content occurs [43], which places it as a good strategy for improving the nutritional quality of vegetable biomass to animal feed. Although fungi are not capable to fix nitrogen, increases in crude protein content were observed here. This increase occurs due to the consumption of other nutrients (like lipids and carbohydrates) during metabolism, reduction in the total amount of biomass, and protein concentration. Thus, part of biomass nitrogen is incorporated into fungi protein, and carbohydrates are converted into fungal biomass and $\mathrm{CO}_{2}$ [53]. Data assayed here showed higher protein increments after fungi colonization in most treatments, comparing to respective untreated material. But some treatments, as in pure JSC with $S$. commune and P. pulmonarius, presented a decrease in protein. This can be indicative of protein use in these species' metabolism when they are in excess. According to some authors [33], the ligninolytic enzymes are produced during the secondary metabolism under conditions of limited nitrogen. Since the protein concentration of pure JCS 
was the highest of all cultivation medium, probably the consumption of carbon-rich material was impaired. The high protein content available during fermentation could induce fungi to use it for their own metabolism.

The large variation in metabolizing protein among different fungal species identified here was also reported by other authors [53], which showed that after 7 weeks of colonization with $P$. eryngii and $L$. edodes, the total amount of CP increased by $23.3-30.9 \%$ in the fungal-treated wheat straw. Authors have also reported increases and decreases in $\mathrm{CP}$ in different fungi rather than white-rot species. Thus, treatment of JSC colonized with ascomycetes (Trichoderma longibrachiatum, Trichoderma harzanium, and Aspergillus niger) promoted a decrease of $26 \%$ of crude protein content, as identified here for $S$. commune and P. pulmonarius. Increments, however, were also reported in treatments of JSC with Aspergillus niger, showing an increase of crude protein content of up to $11.3 \%$ [54, 55]. A previous study with JSC treated with fungi Absidia spinosa and Mucor rouxxi presented increases up to $8 \%$ in crude protein content [56]. Some authors have also demonstrated that fungi treatment with Candida capsuligena, Candida tropicalis, Saccharomyces cerevisae, Aspergillus terricola, Aspergillus oryzae, and Aspergillus niger in CSC biomass promoted an apparent crude protein increase between 8.95 and $22.24 \%$ [57]. As white-rot fungi, basidiomycetes are very efficient organisms in degrading lignin present into lignocellulosic materials (coconut husks and macauba cake), so the addition of these biomasses in the cultivation of fungi benefits the balance between carbon and nitrogen ideal for fungal growth, besides having more protein diluted, which implies in a preferred degradation, contributing to protein concentration in these biomasses $[53,58]$. Finally, as reported in this work, some authors suggested that the increase in protein content may be related to nitrogen fixed in fungi mycelia, being highly related to organic matter losses as well as with other factors such as temperature, $\mathrm{pH}$, nature of fungi, aeration, type of substrate, and heat [59,60,61, 62], so variation would be expected among different species. The degradation of free gossypol and lignocellulosic biomasses promoted by basidiomycetes can also be related to the apparent increase of protein content [57], as higher CP concentrations were, overall, identified in colonization and biomasses treatments showing greater phorbol and FG degradation. However, at present work, no significant correlation was found between increase of protein content and growth rate or degradation rate.

In the colonization process of wood, white-rot fungi secrete several free radicals, aiming to activate the peroxidases enzymes system for degradation. As a protection for cells, these fungi also secrete antioxidative enzymes along with low molecular phenolic derivatives and other organic acids in response to ROS (reactive oxygen species) produced and in response to environmental stressors [63]. In the present work, reductions in antioxidant activity and total phenolic content of colonized biomasses were identified when compared to uncolonized biomasses. Overall, extracts of treatments using $\mathrm{CH}$ as lignocellulosic biomass presented higher antioxidant activity than treatments of pure JCS, CSC, or with MC added. Concerning the uncolonized biomasses, JCS presented higher TEAC concentrations, since Jatropha seed cake is known for its high antioxidant activity [64]. Differences in antioxidant activity results between ABTS and DPPH radical assays were observed. It can occur because some antioxidant agents react rapidly with peroxyl radical in $\mathrm{ABTS}+\cdot$ assay meanwhile, slowly or even inactive to $\mathrm{DPPH} \cdot$. Furthermore, 
DPPH radical discoloration can happen to other reducing agents, contributing to discrepant results [65]. The same results were also observed by other researchers [66], analyzing the colonization of colonized fungi in soybean, with DPPH scavenging free radicals assay varying from 0.6 to $4.4 \mathrm{mg} \mathrm{TEAC} / \mathrm{mg}$ of extract, and only one colonized sample presented TEAC values higher than uncolonized soybean (3.2 TEAC/mg of extract). Besides, other authors have reported antioxidative activities of other molecules, as polysaccharides isolated from Ganoderma atrum, Agaricus bisporus, Lentinus edodes, Lentinus polychrous, and Phellinus linteus $[67,68]$. This may be the reason why there was no correlation between antioxidant activities and TPC at present work. We hypothesize that the assays applied here are detecting other substances with antioxidant activity besides phenolic compounds, like beta-glucans produced by fungi. Other work had isolated polyphenols with antioxidative properties from the culture broth of Inonotus xeranticus, and Phellinus linteus [69], corroborating that fungal bioactive compounds have indeed, antioxidant properties, potentially applied in animal food processing.

Frequently, the antioxidant activity is correlated with the phenolic content of biomasses, as the concentration of antioxidant compounds, as a response to the oxidative stress and free radicals production, is expected to increase as fungi grow [70]. However, the majority of colonized biomasses in this work did not show this similarity between antioxidant activity and TPC content. Not all extracts with a higher amount of total phenolic compounds showed high antioxidant activity and vice versa. Therefore, the hypothesis that is suggested, is that oxidative enzyme production by basidiomycetes related to lignin depolymerization could have affected the antioxidant capacity of the biomasses tested. It's known that oxidases and peroxidases are the main enzymes produced being responsible for generating free radicals that can interfere in the measure of antioxidant activity [71]. Besides, the differences between antioxidant activity and total phenolic compounds results are justified by the existence of other compounds produced by basidiomycetes that can promote antioxidant activity, besides phenolic compounds. Basidiomycetes are known to produce compounds other than phenolic compounds, such as carotenoids, $\mathrm{C}$ and $\mathrm{E}$ vitamins, and $\beta$-glucans that also present antioxidant activities [72].

Choose the best treatment for detoxification and enhancement of biomass is a multicriteria decision and needs to be addressed with appropriate tools. Analytic Hierarchy Process (AHP) was applied to establish the weight of each of the dependent variables. The Analytic Hierarchy Process (AHP) is a theory of measurement through pairwise comparisons and relies on the judgments of experts to derive priority scales. It is these scales that measure intangibles in relative terms. The comparisons are made using a scale of absolute judgments that represents, how much more, one element dominates another with respect to a given attribute [73]. The criteria's selected and weights found were degradation rate of toxic compounds $(0.48)$, protein increase $(0.19)$, final CP content $(0.13)$, ergosterol content $(0,09)$ ABTS radical assay (0.06), and DPPH radical assay (0.04). In conclusion, the most promising treatments for JSC were $P$. pulmonarius and $S$. commune; $P$. lecomtei in $\mathrm{JCS}+\mathrm{CH}$, and $F$. hepatica in $\mathrm{JSC}+\mathrm{MC}$. Treatments with pure JSC did not perform as well as those treatments. In CSC, F. hepatica and $P$. lecomtei in CSC + MC were the most promising treatments followed by $P$. pulmonarius in pure CSC. In this sense, those treatments can be further investigated for their use in animal feed. 


\section{Conclusions}

This study showed that most basidiomycetes fungi were able to degrade phorbol esters and free gossypol to acceptable levels for animal feed, in pure JSC and CSC, and mixed with lignocellulosic biomasses. Increases in protein content were also observed, mainly with the addition of other lignocellulosic material to culture media. Ergosterol, a precursor of vitamin $\mathrm{D}_{2}$ was produced. This bioprocess was proved to be a safe and good choice for the enrichment of non-conventional biomasses for animal feed. P. pulmonarius, F. hepatica, and P. lecomtei presented the best results for both CSC and JSC biomasses.

Antioxidant activity and TPC were reduced after fermentation, possibly due to the production of oxidative enzymes by the fungi. The results of TPC showed that maybe other antioxidant compounds must also have been produced. Therefore, further studies on the quantification of these compounds, possibly carotenoids, vitamins $\mathrm{E}$ or $\mathrm{C}$, $\beta$-glucans, should be conducted to identify the antioxidant source of basidiomycetes colonization.

\section{Declarations}

\section{Acknowledgments}

The authors would like to thank FAPDF (Fundação de Apoio à Pesquisa do Distrito Federal - Federal District Research Support Foundation-01983.001720/2017) and CAPES (Coordenação de Aperfeiçoamento de Pessoal de Nível Superior - Coordination for the Improvement of Higher Education Personnel) for granting scholarships to some of the authors.

\section{Funding}

This research was financially supported by FAPDF (Fundação de Apoio à Pesquisa do Distrito Federal Federal District Research Support Foundation) (0193.001720-2017) and CAPES (Coordenação de Aperfeiçoamento de Pessoal de Nível Superior - Coordination for the Improvement of Higher Education Personnel).

\section{Conflicts of interest/Competing interests}

The authors declare no conflicts of interest or competing interests.

\section{Availability of data and material}

Not applicable.

\section{Code availability}

Not applicable. 


\section{References}

1. Gomes, T.G., Hadi, S.I.I.A., Costa Alves, G.S., Mendonça, S., De Siqueira, F.G., Miller, R.N.G.: Current Strategies for the Detoxification of Jatropha curcas Seed Cake: A Review. J. Agric. Food Chem. (2018). https://doi.org/10.1021/acs.jafc.7b05691

2. Gadelha, I.C.N., Fonseca, N.B.S., Oloris, S.C.S., Melo, M.M., Soto-Blanco, B.: (2014). Gossypol Toxicity from Cottonseed Products. The Scientific World Journal (2015). https://doi.org/10.1155/2014/231635

3. Soares Neto, C.B., Conceição, A.A., Gomes, T.G., et al.: A Comparison of Physical, Chemical, Biological and Combined Treatments for Detoxification of Free Gossypol in Crushed Whole Cottonseed. Waste Biomass Valor (2020). https://doi.org/10.1007/s12649-020-01290-0

4. de Barros, C.R.M., Ferreira, L.M.M., Nunes, F.M., Bezerra, R.M.F., Dias, A.A., Guedes, C.V., Cone, J.W., Marques, G.S.M., Rodrigues, M.A.M.: The potential of white-rot fungi to degrade phorbol esters of Jatropha curcas L. seed cake. Eng. Life Sci. (2011). https://doi.org/10.1002/elsc.201000040

5. Philippoussis, A., Zervakis, G., Diamantopoulou, P.: Bioconversion of agricultural lignocellulosic wastes through the cultivation of the edible mushrooms Agrocybe aegerita, Volvariella volvacea and Pleurotus spp. World Journal of Microbiology and Biotechnology: (2001). https://doi.org/10.1023/A:1016685530312

6. Cavalcanti-Oliveira, E.D., Silva, P.R., Rosa, T.S., Moura, N.M.L., Santos, B.C.P., Carvalho, D.B., Sousa, J.S., Carvalhinho, M.T.J.E., Castro, A.M., Freire, D.M.G.: Methods to prevent acidification of Macauba (Acrocomia aculeata) fruit pulp oil: a promising oil for producing biodiesel. Ind. Crops Prod. (2015) https://doi.org/10.1016/j.indcrop.2015.09.022

7. Miles, P.G., Chang, S.-T.: Mushroom Biology. In Mushroom Biology. WORLD SCIENTIFIC (1997)

8. Bach, F., Helm, C.V., Bellettini, M.B., Maciel, G.M., Haminiuk, C.W.I.: Edible mushrooms: a potential source of essential amino acids, glucans and minerals. Int. J. Food Sci. Technol. (2017). https://doi.org/10.1111/ijfs.13522

9. Rashidi, A., Yang, T.: Nutritional and Antioxidant Values of Oyster Mushroom (P. sajor-caju) Cultivated on Rubber Sawdust. International Journal on Advanced Science, Engineering and Information Technology. (2016). 10.18517/ijaseit.6.2.610

10. Dias, E.S., Abe, C., Schwan, R.F.: Truths and myths about the mushroom Agaricus blazei. Scientia Agricola 61(5), 545-549 (2004)

11. Hetland, G., Johnson, E., Lyberg, T., Bernardshaw, S., Tryggestad, A.M.A., Grinde, B.: Effects of the Medicinal Mushroom Agaricus blazei Murill on Immunity, Infection and Cancer. Scand. J. Immunol. (2008). https://doi.org/10.1111/j.1365-3083.2008.02156.x

12. Bisen, P.S., Baghel, R.K., Sanodiya, B.S., Thakur, G.S., Prasad, G.: Lentinus edodes. a macrofungus with pharmacological activities. Curr. Med. Chem. (2010). https://doi.org/10.2174/092986710791698495

13. (1), 66-71 (2003) 
14. Ruán-Soto, F., Garibay-Orijel, R., Cifuentes, J.: Process and dynamics of traditional selling wild edible mushrooms in tropical Mexico. J. Ethnobiol. Ethnomed. (2006). https://doi.org/10.1186/1746-42692-3

15. Kües, U., Liu, Y.: Fruiting body production in basidiomycetes. Appl. Microbiol. Biotechnol. (2000). https://doi.org/10.1007/s002530000396

16. Carrasco-González, J.A., Serna-Saldívar, S.O., Gutiérrez-Uribe, J.A.: Nutritional composition and nutraceutical properties of the Pleurotus fruiting bodies: Potential use as food ingredient. J. Food Compos. Anal. (2017). https://doi.org/10.1016/j.jfca.2017.01.016

17. Liktor-Busa, E., Kovács, B., Urbán, E., Hohmann, J., Ványolós, A.: Investigation of Hungarian mushrooms for antibacterial activity and synergistic effects with standard antibiotics against resistant bacterial strains. Lett. Appl. Microbiol. (2016). https://doi.org/10.1111/lam.12576

18. Ribeiro, B., Valentão, P., Baptista, P., Seabra, R.M., Andrade, P.B.: Phenolic compounds, organic acids profiles and antioxidative properties of beefsteak fungus (Fistulina hepatica). Food Chem. Toxicol. (2007). https://doi.org/10.1016/j.fct.2007.03.015

19. Vargas-Isla, R., Capelari, M., Menolli, N. Jr., Nagasawa, E., Tokimoto, K., Ishikawa, N.K.: Relationship between Panus lecomtei and $P$. strigellus inferred from their morphological, molecular and biological characteristics. Mycoscience (2015). https://doi.org/10.1016/j.myc.2015.05.004

20. Zmitrovich, I.V., Kovalenko, A.E.: Lentinoid and polyporoid fungi, two generic conglomerates containing important medicinal mushrooms in molecular perspective. International Journal of Medicinal Mushrooms (2016). https://doi.org/10.1615/IntJMedMushrooms.v18.i1.40

21. Cör, D., Botić, T., Knez, Ž, Batista, U., Gregori, A., Pohleven, F., Bončina, T.: Two-stage extraction of antitumor, antioxidant and antiacetylcholinesterase compounds from Ganoderma lucidum fruiting body. J. Supercrit. Fluids (2014). https://doi.org/10.1016/j.supflu.2014.04.006

22. Cör, D., Knez, Ž, Knez Hrnčič, M.: Antitumour, antimicrobial, antioxidant and antiacetylcholinesterase effect of Ganoderma lucidum terpenoids and polysaccharides: A review. Molecules (2018). https://doi.org/10.3390/molecules23030649

23. Tiseo, K., Huber, L., Gilbert, M., Robinson, T.P., Van Boeckel, T.P.: Global Trends in Antimicrobial Use in Food Animals from 2017 to 2030. Antibiotics. (2020). https://doi.org/10.3390/antibiotics 9120918

24. Makkar, H.P.S., Becker, K., Sporer, F., Wink, M.: Studies on nutritive potential and toxic constituents of different provenances of Jatropha curcas. J. Agric. Food Chem. (1997). https://doi.org/10.1021/jf970036j

25. Conceição, A.A., Soares Neto, C.B., Ribeiro, J.AdeA., de Siqueira, F.G., Miller, R.N.G., Mendonça, S.: Development of an RP-UHPLC-PDA method for quantification of free gossypol in cottonseed cake and fungal-treated cottonseed cake. Plos One (2018). https://doi.org/10.1371/journal.pone. 0196164

26. Ng, H.-E., Raj, S., Wong, S., Tey, D., Tan, H.-M.: Estimation of fungal growth using the ergosterol assay: a rapid tool in assessing the microbiological status of grains and feeds. Lett. Appl. Microbiol. (2008). https://doi.org/10.1111/j.1472-765X.2007.02279.x 
27. Steudler, S., Bley, T.: Biomass estimation during macro-scale solid-state fermentation of basidiomycetes using established and novel approaches. Bioprocess. Biosyst. Eng. (2015). https://doi.org/10.1007/s00449-015-1372-0

28. Shuuluka, D., Bolton, J.J., Anderson, R.J.: Protein content, amino acid composition and nitrogen-toprotein conversion factors of Ulva rigida and U/va capensis from natural populations and Ulva lactuca from an aquaculture system, in South Africa. J Appl Phycol: (2013). https://doi.org/10.1007/s10811-012-9902-5

29. Pires, J., Torres, P.B., Santos, D., Chow, F.: Ensaio em microplaca do potencial antioxidante através do método de sequestro do radical livre DPPH para extratos de algas. Instituto de Biociências, Universidade de São Paulo, São Paulo (2017)

30. Silva, E.M., Souza, J.N.S., Rogez, H., Rees, J.-F., Larondelle, Y.: Antioxidant activities and polyphenolic contents of fifteen selected plant species from the Amazonian region. Food Chem. (2007). https://doi.org/10.1016/j.foodchem.2006.02.055

31. Horszwald, A., Andlauer, W.: Characterisation of bioactive compounds in berry juices by traditional photometric and modern microplate methods. Journal of Berry Research (2011). https://doi.org/10.3233/JBR-2011-020

32. Waterhouse, A.L.: Determination of total phenolics. Current Protocols in Food Analytical Chemistry 6(1), I1-I1 (2002)

33. RStudio, T.. . RStudio: RStudio: Integrated Development for R. PBC, Boston (2020). http://www.rstudio.com/

34. Hammel, K.E.: Fungal Degradation of Lignin. In: Cadisch, G. and Giller, K.E. (Eds) Driven by Nature: Plant Litter Quality and Decomposition, International, C.A.B., 33-45. Wallingford: (1997). https://doi.org/10.1016/j.tifs.2017.06.012

35. Owaid, M.N., Barish, A., Shariati, M.A.: Cultivation of Agaricus bisporus (button mushroom) and its usages in the biosynthesis of nanoparticles. Open Agriculture. 2(1), 537-543 (2017)

36. Rossi, I.H., Monteiro, A.C., Machado, J.O., Andrioli, J.L., Barbosa, J.C.: Shiitake (Lentinula edodes) production on a sterilized bagasse substrate enriched with rice bran and sugarcane molasses. Brazilian Journal of Microbiology. (2003). http://dx.doi.org/10.1590/S1517-83822003000100014

37. Pardo-Giménez, A., Pardo, J.E., Dias, E.S., et al.: Optimization of cultivation techniques improves the agronomic behavior of Agaricus subrufescens. Sci Rep (2020). https://doi.org/10.1038/s41598-02065081-2

38. Boyle, C.D.: Nutritional factors limiting the growth of Lentinula edodes and other whiterot fungi in wood. Soil Biol. Biochem. 30(6), 817-823 (1998)

39. Kalberer, P.P.: Influence of urea and ammonium chloride on crop yield and fruit body size of shiitake (Lentinula edodes). Mush. Sci. 15, 361-366 (2000)

40. Rodrigues da Luz, J.M., Nunes, M.D., Paes, S.A., Torres, D.P., Kasuya, M.C.M.: Bio-detoxification of Jatropha curcas seed cake by Pleurotus ostreatus. African Journal of Microbiology Research (2014). https://doi.org/10.5897/AJMR2014.6617 
41. Khan, N.A., Yasin, O., Aslam, H.M.U., Ikram, A., Maqbool, R., Akhtar, M., Asif, M., Khan, S.A., Javed, N.: Yield improvement of oyster mushroom (Pleurotus ostreatus) production using cotton seed cake with combination of wheat straw amended with rice bran cellulosic waste materials. Int. J. Biosci (2019). http://dx.doi.org/10.12692/ijb/14.2.340-349

42. Basso, V., Schiavenin, C., Mendonça, S., Siqueira, F.G., Salvador, M., Camassola, M.: Chemical features and antioxidant profile by Schizophyllum commune produced on different agroindustrial wastes and byproducts of biodiesel production. Food Chem. (2020) https://doi.org/10.1016/j.foodchem.2020.127089

43. Castro, C.P.: Characterization and ileal digestibility of cotton seed cake pre-traded by the macrobasidiomycete Fistulina hepatica CC102 in swines diets. Dissertation (Master in Agricultural Microbiology) - Federal University of Lavras. (2018)

44. Bose, A., Keharia, H.: Phorbol ester degradation in Jatropha seedcake using white rot fungi. Biotech. (2014). https://doi.org/10.1007/s13205-013-0174-9

45. Corrêa, R.C.G., Peralta, R.M., Bracht, A., Ferreira, I.C.F.R.: The emerging use of mycosterols in food industry along with the current trend of extended use of bioactive phytosterols. Trends Food Sci. Technol. (2017). https://doi.org/10.1016/j.tifs.2017.06.012

46. Mille-Lindblom, C., von Wachenfeldt, E., Tranvik, L.J.: Ergosterol as a measure of living fungal biomass: persistence in environmental samples after fungal death. J. Microbiol. Methods. (2004). https://doi.org/10.1016/j.mimet.2004.07.010

47. Barreira, J.C.M., Oliveira, M.B.P.P., Ferreira, I.C.F.R.: Development of a Novel Methodology for the Analysis of Ergosterol in Mushrooms. Food Anal. Methods (2014). https://doi.org/10.1007/s12161013-9621-9

48. Ballaminut, N., Matheus, D.R.: Characterization of fungal inoculum used in soil bioremediation. Brazilian Journal of Microbiology. (2007). http://dx.doi.org/10.1590/S1517-83822007000200011

49. Niemenmaa, O., Galkin, S., Hatakka, A.: and Ergosterol contents of some wood-rotting basidiomycete fungi grown in liquid and solid culture conditions. Biodegradation. (2008). https://doi.org/10.1016/j.ibiod.2007.12.009

50. Duffy, S.K., Kelly, A.K., Rajauria, G., Jakobsen, J., Clarke, L.C., Monahan, F.J., Dowling, K.G., Hull, G., Galvin, K., Cashman, K.D., Hayes, A., O'Doherty, J.V.: The use of synthetic and natural vitamin D sources in pig diets to improve meat quality and vitamin D content. Meat Sci. (2018). https://doi.org/10.1016/j.meatsci.2018.04.014

51. Kasuya, M.C.M., da Luz, J.M.R., Pereira, L.P.S., da Silva, J.S., Montavani, H.C., Rodrigues, M.T.: BioDetoxification of Jatropha Seed Cake and Its Use in Animal Feed. In: Fang, Z. (ed.) Biodiesel, pp. 309-330. (2012) DOI: 10.5772/52157

52. Rajarathnam, S., Shashirekha, M.N., Bano, Z.: Biodegradation of gossypol by the white oyster mushroom, Pleurotus florida, during culturing on rice straw growth substrate, supplemented with cottonseed powder. World J Microbiol Biotechnol. (2001) https://doi.org/10.1023/A:1016603510901 
53. Araujo, A.P.F.: Tratamento de torta de semente de algodão por autoclavagem e macrofungos para degradação de gossypol. Dissertação de Mestrado Acadêmico. Universidade Federal de Tocantins. Curso de Pós Graduação em Biotecnologia. 89f. 2018

54. Nayan, N., Sonnenberg, A.S.M., Hendriks, W.H., Cone, J.W.:Variation in the solubilization of crude protein in wheat straw by different white-rot fungi. Anim. Feed Sci. Technol. (2018). https://doi.org/10.1016/j.anifeedsci.2018.06.009

55. Belewu, M.A., Ahmed, O., Ibrahim, S.O.: Solid state fermentation of Jatropha curcas kernel cake with cocktail of fungi. Int. J. Biosci. 1(1), 12-19 (2011)

56. Ojediran, T.K., Ogunmola, B.T., Ajayi, A.O., Adepoju, M.A., Odelade, K., Emiola, I.A. Nutritive value of processed dietary fungi treated Jatropha curcas $L$. kernel meals: voluntary intake, growth, organ weight and hepatic histology of broiler chicks. Tropical Agriculture: (2016). https://doi.org/00413216/2016/020101-10

57. Sanusi, G.O., Belewu, M.A., Oduguwa, B.O., Enujiugha, T.F., Oluwole, J.Y.T., Okunlola, A.I.: Changes in chemical composition of Jatropha curcas kernel cake after solid-state fermentation using some selected fungi. Global J. Biol. Agric. Health Sci. 2(2), 62-66 (2013)

58. Zhang, W., Xu, Z., Sun, J., Yang, X.: Effect of selected fungi on the reduction of gossypol levels and nutritional value during solid substrate fermentation of cottonseed meal. Journal of Zhejiang University Science B (2006). https://doi.org/10.1631/jzus.2006.B0690

59. Metri, Y., Warly, L., Suyitman: Biodegradation of Lignin by White Rot Fungi (Pleurotus ostreatus) to Decrease the Fibre Components in the Palm Midrib. Pakistan Journal of Nutrition. (2018). DOI:10.3923/pjn.2018.71.75

60. Zadrazil, F., Diedrichs, M., Janssen, H., Schuchardt, F., Park, J.S.: Large scale solid state fermentation of cereal straw with Pleurotus spp. Advances in Biological Treatment of Lignocellulosic Materials. pp. 31-41. (1990)

61. Karunanandaa, K., Fales, S.L., Varga, G.A., Royse, D.J.: Chemical composition and biodegradability of crop residues colonized by white-rot fungi. J. Sci. Food Agric. (1992). https://doi.org/10.1002/jsfa.2740600117

62. Tripathi, M.K., Mishra, A.S., Misra, A.K., Vaithiyanathan, S., Prasad, R., Jakhmola, R.C.: Selection of white-rot basidiomycetes for bioconversion of mustard (Brassica compestris) straw under solid-state fermentation into energy substrate for rumen micro-organism. Lett. Appl. Microbiol. (2008). https://doi.org/10.1111/j.1472-765X.2008.02320.x

63. Yang, H., Zhang, L.: Changes in some components of soymilk during fermentation with the basidiomycete Ganoderma lucidum. Food Chem. (2009). https://doi.org/10.1016/j.foodchem.2008.05.024

64. Chandra, P., Arora, D.S., Pal, M., Sharma, R.K.: Antioxidant Potential and Extracellular Auxin Production by White Rot Fungi. Appl. Biochem. Biotechnol. (2019). https://doi.org/10.1007/s12010018-2842-z 
65. Nithiyanantham, S., Siddhuraju, P., Francis, G.: Potential of Jatropha curcas as a biofuel, animal feed and health products. Journal of the American Oil Chemists' Society (2012). https://doi.org/10.1007/s11746-012-2012-3

66. Prior, R.L., Wu, X., Schaich, K.: Standardized methods for the determination of antioxidant capacity and phenolics in foods and dietary supplements. J. Agric. Food Chem. (2005). https://doi.org/10.1021/jf0502698

67. Lin, C.-H., Wei, Y.-T., Chou, C.-C.: Enhanced antioxidative activity of soybean koji prepared with various filamentous fungi. Food Microbiol. (2006). https://doi.org/10.1016/j.fm.2005.12.004

68. Thetsrimuang, C., Khammuang, S., Chiablaem, K., Srisomsap, C., Sarnthima, R.: Antioxidant properties and cytotoxicity of crude polysaccharides from Lentinus polychrous Lév. Food Chem. (2011). https://doi.org/10.1016/j.foodchem.2011.03.077

69. Chen, Y., Xie, M.-Y., Nie, S.-P., Li, C., Wang, Y.-X.: Purification, composition analysis and antioxidant activity of a polysaccharide from the fruiting bodies of Ganoderma atrum. Food Chem. (2008). https://doi.org/10.1016/j.foodchem.2007.08.021

70. Jung, J.-Y., Lee, I.-K., Seok, S.-J., Lee, H.-J., Kim, Y.-H., Yun, B.-S.: Antioxidant polyphenols from the mycelial culture of the medicinal fungi Inonotus xeranticus and Phellinus linteus. J. Appl. Microbiol. (2008). https://doi.org/10.1111/j.1365-2672.2008.03737.x

71. Barros, L., Ferreira, I., Baptista, P.: Phenolics and Antioxidant Activity of Mushroom Leucopaxillus giganteus Mycelium at Different Carbon Sources. Food Science and Technology International - FOOD SCI TECHNOL (2008). 10.1177/1082013208090094

72. Kersten, P., Cullen, D.: Extracellular oxidative systems of the lignin-degrading Basidiomycete Phanerochaete chrysosporium. Fungal Genet. Biol. (2007).

https://doi.org/10.1016/j.fgb.2006.07.007

73. Zhai, F.-H., Wang, Q., Han, J.-R.: Nutritional components and antioxidant properties of seven kinds of cereals colonized by the basidiomycete Agaricus blazei. J. Cereal Sci. (2015). https://doi.org/10.1016/j.jcs.2015.07.010

74. Saaty, T.: How to Make a Decision: The Analytic Hierarchy Process. Interfaces. (1994). http://www.jstor.org/stable/25061950

\section{Tables}

Table 1 Phorbol ester content $(\mathrm{mg} / \mathrm{g})$ and degradation (\%), ergosterol content (ppm), crude protein content (g/100g d.w.) and crude protein difference (\%) of five basidiomycetes colonized in jatropha seed cake, jatropha seed cake with coconut husks and jatropha seed cake with macauba cake. 


\begin{tabular}{|c|c|c|c|c|c|c|}
\hline Treatment & Biomass & $\begin{array}{c}\text { Phorbol ester } \\
\text { (mg/g) }\end{array}$ & $\begin{array}{c}\text { Phorbol ester } \\
\text { degradation (\%) }\end{array}$ & $\begin{array}{l}\text { Ergosterol } \\
\text { (ppm) }\end{array}$ & $\begin{array}{c}\text { CP } \\
\text { g/100g } \\
\text { d.w.) }\end{array}$ & $\begin{array}{l}\text { ifference } \\
\text { (\%) }\end{array}$ \\
\hline \multirow{3}{*}{ Uncolonized } & JSC & $1.16 \pm 0.05^{\mathrm{Aa}}$ & - & $52.5 \pm 7.7^{\mathrm{Ba}}$ & $27.9 \pm 1.2^{\mathrm{ABa}}$ & - \\
\hline & $\mathrm{JSC}+\mathrm{CH}$ & $0.42 \pm 0.04^{\mathrm{Ab}}$ & - & $40.9 \pm 1.4^{\mathrm{Ca}}$ & $11.4 \pm 0.4^{\mathrm{Bc}}$ & - \\
\hline & $\mathrm{JSC}+\mathrm{MC}$ & $0.47 \pm 0.08^{\mathrm{Ab}}$ & - & $35.3 \pm 0.7^{\mathrm{Ca}}$ & $16.9 \pm 1.6^{\mathrm{Cb}}$ & - \\
\hline \multirow{6}{*}{ S. commune } & JSC & $0.19 \pm 0.02^{\mathrm{Ba}}$ & $83.4 \pm 1.9^{\mathrm{Aa}}$ & $243.7 \pm$ & $23.3 \pm$ & $-16.9 \pm$ \\
\hline & & & & $138.9^{\mathrm{ABb}}$ & $4.5^{\mathrm{BCa}}$ & $16.3^{\mathrm{BCc}}$ \\
\hline & $\mathrm{JSC}+\mathrm{CH}$ & $0.08 \pm 0.01^{\mathrm{Cb}}$ & $80.5 \pm 1.8^{\mathrm{Aa}}$ & $1261.4 \pm$ & $17.3 \pm 1.2^{\mathrm{Ab}}$ & $51.5 \pm 10.8^{\mathrm{Aa}}$ \\
\hline & & & & $136.7^{\mathrm{Aa}}$ & & \\
\hline & $\mathrm{JSC}+\mathrm{MC}$ & $0.06 \pm 0.01^{\mathrm{Bc}}$ & $86.4 \pm 3.3^{\mathrm{Aa}}$ & $1268.7 \pm$ & $20.0 \pm$ & $18.5 \pm$ \\
\hline & & & & $140.0^{\mathrm{Aa}}$ & $2.8^{\mathrm{ABCa}}$ & $16.7^{\mathrm{ABb}}$ \\
\hline \multirow{6}{*}{ pulmonarius } & JSC & $0.09 \pm 0.03^{\mathrm{Ba}}$ & $92.1 \pm 9.8^{\mathrm{Aa}}$ & $476.2 \pm 96.2^{\mathrm{Aa}}$ & $20.8 \pm 3.4^{\mathrm{Ca}}$ & $-25.7 \pm$ \\
\hline & & & & & & $12.2^{\mathrm{Cc}}$ \\
\hline & $\mathrm{JSC}+\mathrm{CH}$ & $0.02 \pm 0.01^{\mathrm{Cb}}$ & $94.9 \pm 1.2^{\mathrm{Aa}}$ & $763.1 \pm$ & $17.9 \pm 2.4^{\mathrm{Aa}}$ & $56.6 \pm 20.8^{\mathrm{Aa}}$ \\
\hline & & & & $297.2^{\mathrm{ABa}}$ & & \\
\hline & $\mathrm{JSC}+\mathrm{MC}$ & $0.01 \pm 0.00^{\mathrm{Bc}}$ & $98.0 \pm 0.8^{\mathrm{Aa}}$ & $694.1 \pm 137.6^{\mathrm{Ba}}$ & $18.7 \pm$ & $10.8 \pm 9.3^{\mathrm{Bb}}$ \\
\hline & & & & & $1.6^{\mathrm{BCa}}$ & \\
\hline \multirow{3}{*}{ F. hepatica } & JSC & $0.06 \pm 0.01^{\mathrm{Bb}}$ & $94.7 \pm 3.5^{\mathrm{Aa}}$ & $289.9 \pm 45.4^{\mathrm{ABb}}$ & $30.0 \pm 3.9^{\mathrm{Aa}}$ & $7.6 \pm 13.8^{\mathrm{Ac}}$ \\
\hline & $\mathrm{JSC}+\mathrm{CH}$ & $0.10 \pm 0.03^{\mathrm{Ca}}$ & $75.3 \pm 7.1^{\mathrm{Bb}}$ & $588.2 \pm 112.1^{\mathrm{Ba}}$ & $19.7 \pm 1.4^{\mathrm{Ac}}$ & $72.0 \pm 12.2^{\mathrm{Aa}}$ \\
\hline & $\mathrm{JSC}+\mathrm{MC}$ & $0.06 \pm 0.01^{\mathrm{Bb}}$ & $86.9 \pm 6.8^{\mathrm{Aab}}$ & $198.2 \pm 46.4^{\mathrm{Cb}}$ & $22.5 \pm 2.1^{\mathrm{Ab}}$ & $33.7 \pm 12.6^{\mathrm{Ab}}$ \\
\hline \multirow{5}{*}{ P. lecomtei } & JSC & $0.02 \pm 0.01^{\mathrm{Ba}}$ & $98.2 \pm 0.5^{\mathrm{Aa}}$ & $382.0 \pm 19.1^{\mathrm{Aab}}$ & $28.3 \pm 1.5^{\mathrm{ABa}}$ & $1.2 \pm 5.3^{\mathrm{ABb}}$ \\
\hline & $\mathrm{JSC}+\mathrm{CH}$ & $0.02 \pm 0.00^{\mathrm{Ca}}$ & $94.2 \pm 0.7^{\mathrm{Ab}}$ & $675.8 \pm$ & $16.9 \pm 2.3^{\mathrm{Ab}}$ & $47.5 \pm 19.9^{\mathrm{Aa}}$ \\
\hline & & & & $184.3^{\mathrm{ABa}}$ & & \\
\hline & $\mathrm{JSC}+\mathrm{MC}$ & $0.01 \pm 0.00^{\mathrm{Bb}}$ & $97.3 \pm 0.4^{\mathrm{Aa}}$ & $309.5 \pm 32.4^{\mathrm{Cb}}$ & $19.6 \pm$ & $16.4 \pm$ \\
\hline & & & & & $3.2^{\mathrm{ABCb}}$ & $19.2^{\mathrm{ABb}}$ \\
\hline \multirow{3}{*}{ G. lucidum } & JSC & $0.13 \pm 0.03^{\mathrm{Bb}}$ & $88.7 \pm 0.6^{\mathrm{Aa}}$ & $348.7 \pm 19.8^{\mathrm{Ab}}$ & $30.1 \pm 4.2^{\mathrm{Aa}}$ & $7.8 \pm 15.1^{\mathrm{Ab}}$ \\
\hline & $\mathrm{JSC}+\mathrm{CH}$ & $0.24 \pm 0.08^{\mathrm{Ba}}$ & $53.8 \pm 2.3^{\mathrm{Cb}}$ & $845.1 \pm$ & $19.1 \pm 2.8^{\mathrm{Ab}}$ & $66.6 \pm 24.3^{\mathrm{Aa}}$ \\
\hline & & & & $243.4^{\mathrm{ABa}}$ & & \\
\hline
\end{tabular}




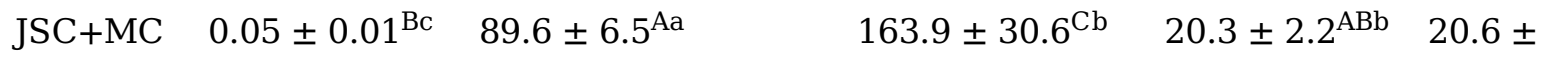

$$
\begin{aligned}
& 13.3^{\mathrm{ABb}}
\end{aligned}
$$

d.w.: dried weight; CP: Crude protein; JSC: Jatropha seed cake; CH: Coconut husks; MC: Macauba cake. Means followed by the same letter are not different by Tukey test $(p<0,05)$. Capital letters represent differences between treatments in the same biomass, and lowercase letters represent differences between biomasses in the same treatment.

Table 2 Gossypol content (ppm) and degradation (\%), ergosterol content (ppm), crude protein content ( $\mathrm{g} / 100 \mathrm{~g}$ d.w.) and crude protein difference (\%) of five basidiomycetes colonized in cottonseed cake, cottonseed cake with coconut husks and cottonseed cake with macauba cake. 


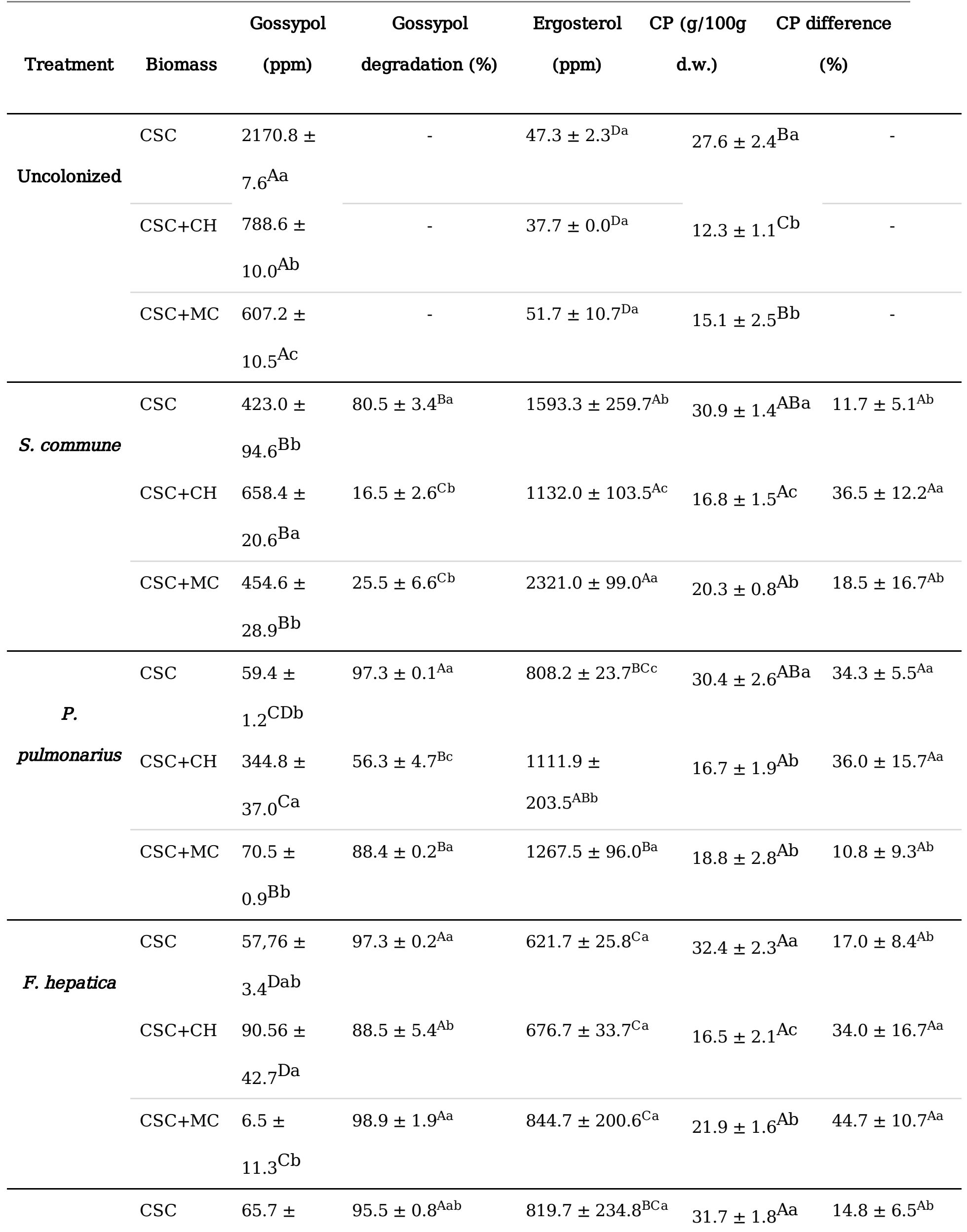


$17.0^{\mathrm{CDa}}$

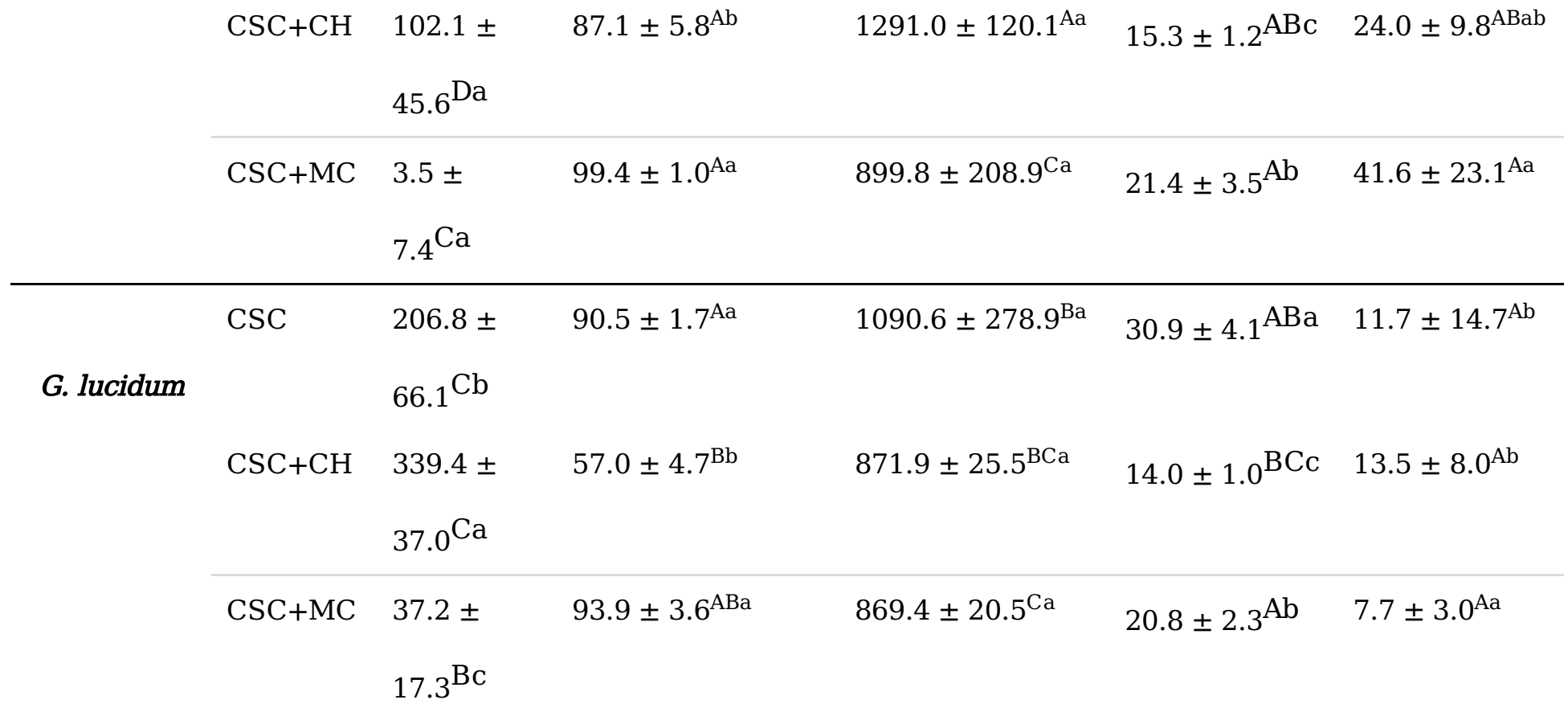

d.w.: dried weight; CP: crude protein; CSC: cottonseed cake; CH: coconut husks; MC: macauba cake. Means followed by the same letter are not different by Tukey test $(p<0,05)$. Capital letters represent differences between treatments in the same biomass and lowercase letters represent differences between biomasses in the same treatment.

Table 3 Antioxidant activity and total phenolic of pure Jatropha seed cake and Jatropha seed cake with lignocellulosic material (coconut husks and macauba cake) treated with five basidiomycetes. 


\begin{tabular}{|c|c|c|c|c|}
\hline Treatment & Biomass & $\begin{array}{c}\text { DPPH• (ug Trolox/mg } \\
\text { extract) }\end{array}$ & $\begin{array}{c}\text { ABTS }+\cdot \text { (ug Trolox/mg } \\
\text { extract) }\end{array}$ & $\begin{array}{c}\text { TPC } \\
\text { (ug GA/mg } \\
\text { extract) }\end{array}$ \\
\hline \multirow[t]{3}{*}{ Uncolonized } & JSC & $109.4 \pm 1.0^{\mathrm{Aa}}$ & $147.9 \pm 9.3^{\mathrm{Ac}}$ & $49.3 \pm 4.5^{\mathrm{Aa}}$ \\
\hline & $\mathrm{JSC}+\mathrm{CH}$ & $77.3 \pm 3.1^{\mathrm{Ab}}$ & $202.9 \pm 0.8^{\mathrm{Aa}}$ & $36.7 \pm 1.7^{\mathrm{Ab}}$ \\
\hline & $\mathrm{JSC}+\mathrm{MC}$ & $80.8 \pm 2.5^{\mathrm{Ab}}$ & $176.4 \pm 5.5^{\mathrm{Ab}}$ & $30.8 \pm 3.2^{\mathrm{Ab}}$ \\
\hline \multirow[t]{3}{*}{ S. commune } & JSC & $31.0 \pm 13.7^{\mathrm{Ba}}$ & $40.4 \pm 12.5^{\mathrm{Ba}}$ & $20.5 \pm 0.3^{\mathrm{Ba}}$ \\
\hline & $\mathrm{JSC}+\mathrm{CH}$ & $15.0 \pm 4.7^{\mathrm{Ca}}$ & $64.5 \pm 7.9^{\mathrm{BCa}}$ & $6.8 \pm 1.2^{\mathrm{Bb}}$ \\
\hline & $\mathrm{JSC}+\mathrm{MC}$ & $17.8 \pm 1.6^{\mathrm{BCa}}$ & $19.5 \pm 9.5^{\mathrm{Ca}}$ & $7.7 \pm 1.5^{\mathrm{BCb}}$ \\
\hline$P$. & JSC & $17.9 \pm 4.1^{\mathrm{BCa}}$ & $18.5 \pm 8.8^{\mathrm{Bb}}$ & $10.5 \pm 1.7^{\mathrm{Ca}}$ \\
\hline \multirow[t]{2}{*}{ pulmonarius } & $\mathrm{JSC}+\mathrm{CH}$ & $56.0 \pm 5.5^{\mathrm{Ba}}$ & $97.2 \pm 23.6^{\mathrm{Ba}}$ & $8.7 \pm 2.5^{\mathrm{Bb}}$ \\
\hline & $\mathrm{JSC}+\mathrm{MC}$ & $15.9 \pm 3.6^{\mathrm{Ca}}$ & $27.0 \pm 13.6^{\mathrm{Cb}}$ & $0.0 \pm 0.0^{\mathrm{Db}}$ \\
\hline \multirow[t]{3}{*}{ F. hepatica } & JSC & $8.0 \pm 3.9^{\mathrm{BCa}}$ & $29.3 \pm 8.3^{\mathrm{Bb}}$ & $4.0 \pm 2.3^{\mathrm{Cb}}$ \\
\hline & $\mathrm{JSC}+\mathrm{CH}$ & $14.5 \pm 2.6^{\mathrm{Ca}}$ & $43.7 \pm 8.1^{\mathrm{BCab}}$ & $10.2 \pm 1.7^{\mathrm{Ba}}$ \\
\hline & $\mathrm{JSC}+\mathrm{MC}$ & $27.8 \pm 5.2^{\mathrm{Ba}}$ & $55.1 \pm 6.3^{\mathrm{Ca}}$ & $9.2 \pm 2.7^{\mathrm{Bab}}$ \\
\hline \multirow[t]{3}{*}{ P. lecomtei } & JSC & $2.4 \pm 0.2^{\mathrm{Cb}}$ & $42.1 \pm 3.7^{\mathrm{Ba}}$ & $0.0 \pm 0.0^{\mathrm{Cb}}$ \\
\hline & $\mathrm{JSC}+\mathrm{CH}$ & $12.3 \pm 4.4^{\mathrm{Cab}}$ & $23.2 \pm 3.2^{\mathrm{Ca}}$ & $14.0 \pm 0.7^{\mathrm{Ba}}$ \\
\hline & $\mathrm{JSC}+\mathrm{MC}$ & $23.6 \pm 1.1^{\mathrm{BCa}}$ & $6.4 \pm 0.9^{\mathrm{Ca}}$ & $0.0 \pm 0.0^{\mathrm{Db}}$ \\
\hline \multirow[t]{3}{*}{ G. lucidum } & JSC & $19.1 \pm 6.2^{\mathrm{BCa}}$ & $62.4 \pm 13.6^{\mathrm{Ba}}$ & $17.3 \pm 3.0^{\mathrm{Bab}}$ \\
\hline & $\mathrm{JSC}+\mathrm{CH}$ & $54.3 \pm 1.7^{\mathrm{Ba}}$ & $48.7 \pm 8.7^{\mathrm{BCa}}$ & $31.8 \pm 6.8^{\mathrm{Aa}}$ \\
\hline & $\mathrm{JSC}+\mathrm{MC}$ & $26.5 \pm 5.2^{\mathrm{BCa}}$ & $35.3 \pm 9.5^{\mathrm{Ca}}$ & $4.0 \pm 0.3^{\mathrm{CDb}}$ \\
\hline
\end{tabular}

TPC: Total phenolic content; GA: Gallic acid; JSC: Jatropha seed cake; CH: coconut husks; MC: macauba cake. Means followed by the same letter are not different by Tukey test $(p<0,05)$. Capital letters represent differences between treatments in the same biomass and lowercase letters represent differences between biomasses in the same treatment.

Table 4. Antioxidant activity and total phenolic of pure cottonseed cake and cottonseed cake with lignocellulosic material (coconut husks and macauba cake) treated with five basidiomycetes. 


\begin{tabular}{|c|c|c|c|c|}
\hline Treatment & Biomass & $\begin{array}{c}\text { DPPH• (ug Trolox/mg } \\
\text { extract) }\end{array}$ & $\begin{array}{c}\text { ABTS }+\cdot(\text { (ug Trolox/mg } \\
\text { extract) }\end{array}$ & $\begin{array}{c}\text { TPC } \\
\text { (ug GA/mg } \\
\text { extract) }\end{array}$ \\
\hline \multirow[t]{3}{*}{ Uncolonized } & $\mathrm{CSC}$ & $53.5 \pm 1.9^{\mathrm{Aa}}$ & $122.1 \pm 7.6^{\mathrm{Ab}}$ & $21.3 \pm 1.2^{\mathrm{Aa}}$ \\
\hline & $\mathrm{CSC}+\mathrm{CH}$ & $34.6 \pm 3.7^{\mathrm{Ab}}$ & $125.9 \pm 3.3^{\mathrm{Ab}}$ & $24.3 \pm 1.0^{\mathrm{Aa}}$ \\
\hline & $\mathrm{CSC}+\mathrm{MC}$ & $42.3 \pm 3.3^{\mathrm{Aa}}$ & $147.9 \pm 7.0^{\mathrm{Aa}}$ & $16.0 \pm 2.2^{\mathrm{Ab}}$ \\
\hline \multirow[t]{3}{*}{ S. commune } & CSC & $14.1 \pm 9.1^{\mathrm{Cb}}$ & $37.2 \pm 22.6^{\mathrm{BCb}}$ & $12.0 \pm 3.7^{\mathrm{Ba}}$ \\
\hline & $\mathrm{CSC}+\mathrm{CH}$ & $19.5 \pm 2.9^{\mathrm{BCa}}$ & $56.2 \pm 7.3^{\mathrm{Ca}}$ & $9.3 \pm 3.3^{\mathrm{Ba}}$ \\
\hline & $\mathrm{CSC}+\mathrm{MC}$ & $16.0 \pm 1.2^{\mathrm{Ba}}$ & $48.2 \pm 7.8^{\mathrm{Ba}}$ & $0.0 \pm 0.0^{\mathrm{Ba}}$ \\
\hline$P$. & $\mathrm{CSC}$ & $12.3 \pm 2.9^{\mathrm{BCa}}$ & $23.1 \pm 7.0^{\mathrm{Cb}}$ & $5.8 \pm 0.7^{\mathrm{BCb}}$ \\
\hline \multirow[t]{2}{*}{ pulmonarius } & $\mathrm{CSC}+\mathrm{CH}$ & $11.0 \pm 2.4^{\mathrm{Ca}}$ & $34.9 \pm 6.5^{\mathrm{Ba}}$ & $9.2 \pm 0.9^{\mathrm{Ba}}$ \\
\hline & $\mathrm{CSC}+\mathrm{MC}$ & $18.7 \pm 10.4^{\mathrm{Ba}}$ & $15.3 \pm 0.9^{\mathrm{Cb}}$ & $0.0 \pm 0.0^{\mathrm{Bc}}$ \\
\hline \multirow[t]{3}{*}{ F. hepatica } & $\mathrm{CSC}$ & $4.8 \pm 4.6^{\mathrm{Cb}}$ & $23.1 \pm 7.0^{\mathrm{BCb}}$ & $12.8 \pm 2.0^{\mathrm{Aba}}$ \\
\hline & $\mathrm{CSC}+\mathrm{CH}$ & $20.2 \pm 0.6^{\mathrm{Ba}}$ & $52.6 \pm 6.4^{\mathrm{CDa}}$ & $14.5 \pm 3.7^{\mathrm{Aba}}$ \\
\hline & $\mathrm{CSC}+\mathrm{MC}$ & $18.9 \pm 0.6^{\mathrm{Ba}}$ & $30.8 \pm 2.4^{\mathrm{BCb}}$ & $17.0 \pm 2.3^{\mathrm{Aa}}$ \\
\hline \multirow[t]{3}{*}{ P. lecomtei } & $\mathrm{CSC}$ & $4.2 \pm 3.7^{\mathrm{BCa}}$ & $15.3 \pm 6.2^{\mathrm{BCa}}$ & $1.7 \pm 0.2^{\mathrm{Ca}}$ \\
\hline & $\mathrm{CSC}+\mathrm{CH}$ & $15.4 \pm 5.5^{\mathrm{BCa}}$ & $24.6 \pm 3.5^{\mathrm{Da}}$ & $2.3 \pm 1.8^{\mathrm{Ba}}$ \\
\hline & $\mathrm{CSC}+\mathrm{MC}$ & $21.3 \pm 9.9^{\mathrm{Ba}}$ & $13.8 \pm 2.6^{\mathrm{Ca}}$ & $0.0 \pm 0.0^{\mathrm{Ba}}$ \\
\hline \multirow[t]{3}{*}{ G. lucidum } & $\mathrm{CSC}$ & $13.1 \pm 6.5^{\mathrm{Ba}}$ & $34.5 \pm 6.8^{\mathrm{B}}$ & $14.0 \pm 5.3^{\mathrm{Aba}}$ \\
\hline & $\mathrm{CSC}+\mathrm{CH}$ & $19.5 \pm 3.3^{\mathrm{BCa}}$ & $56.6 \pm 18.2^{\mathrm{C}}$ & $7.2 \pm 4.5^{\mathrm{Bab}}$ \\
\hline & $\mathrm{CSC}+\mathrm{MC}$ & $19.5 \pm 10.8^{\mathrm{Ba}}$ & $34.1 \pm 4.7^{\mathrm{BC}}$ & $0.0 \pm 0.0^{\mathrm{Bb}}$ \\
\hline
\end{tabular}

TPC: Total phenolic content; GA: Gallic acid; CSC: Cottonseed cake; CH: Coconut husks; MC: Macauba cake. Means followed by the same letter are not different by Tukey test $(p<0,05)$. Capital letters represent differences between treatments in the same biomass and lowercase letters represent differences between biomasses in the same treatment.

\section{Supplementary Material}

Supplementary material is not available in this version.

\section{Figures}


a

JSC
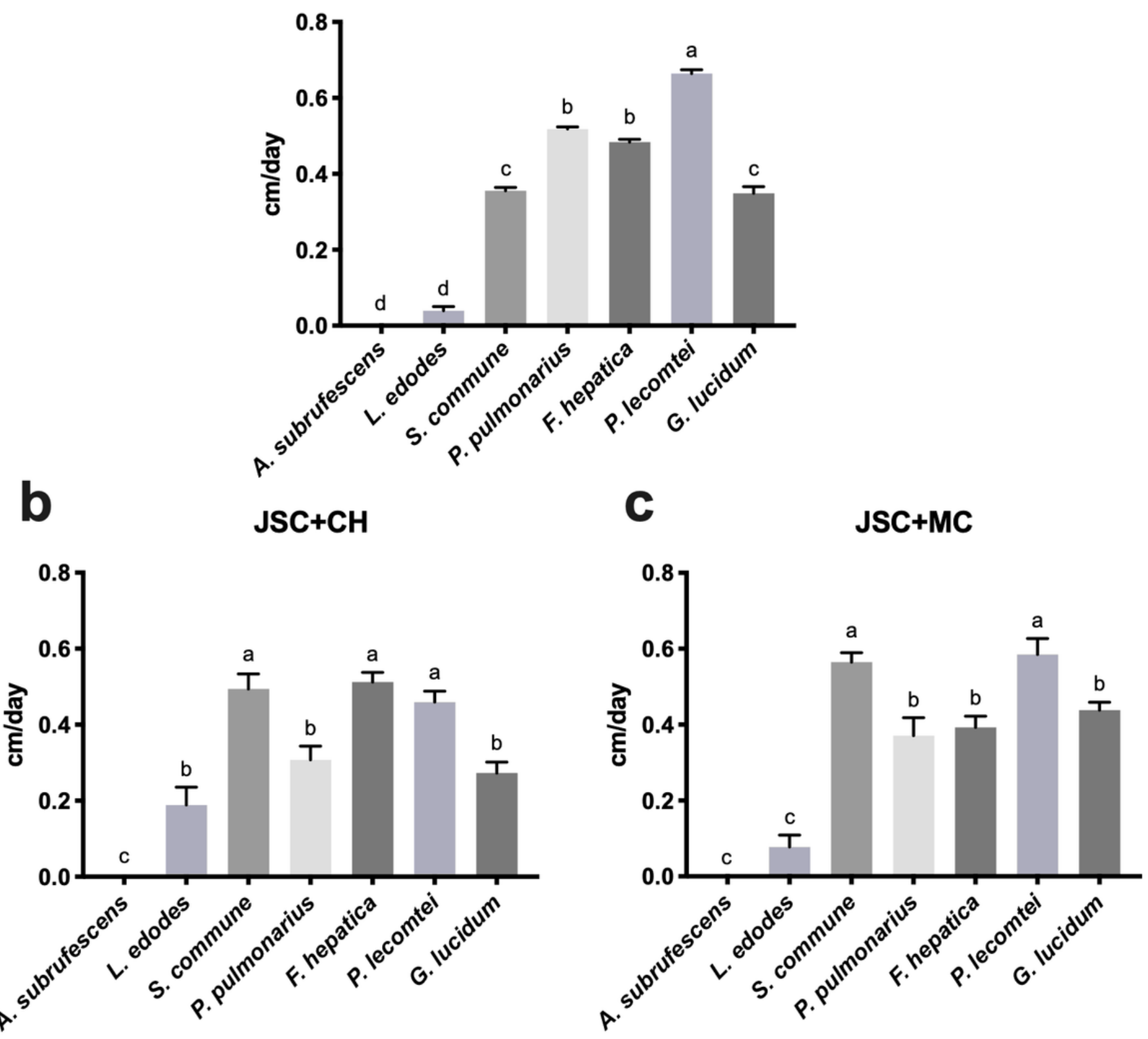

Figure 1

Growth rate (cm/day) of seven basidiomycetes colonized in jatropha seed cake, jatropha seed cake with coconut husks and jatropha seed cake with macauba cake during 15 days in $10 \mathrm{~cm}$ jars. JSC: Jatropha seed cake; $\mathrm{CH}$ : Coconut husks; MC: Macauba cake. Means followed by the same letter are not different by Tukey test $(p<0,05)$. 


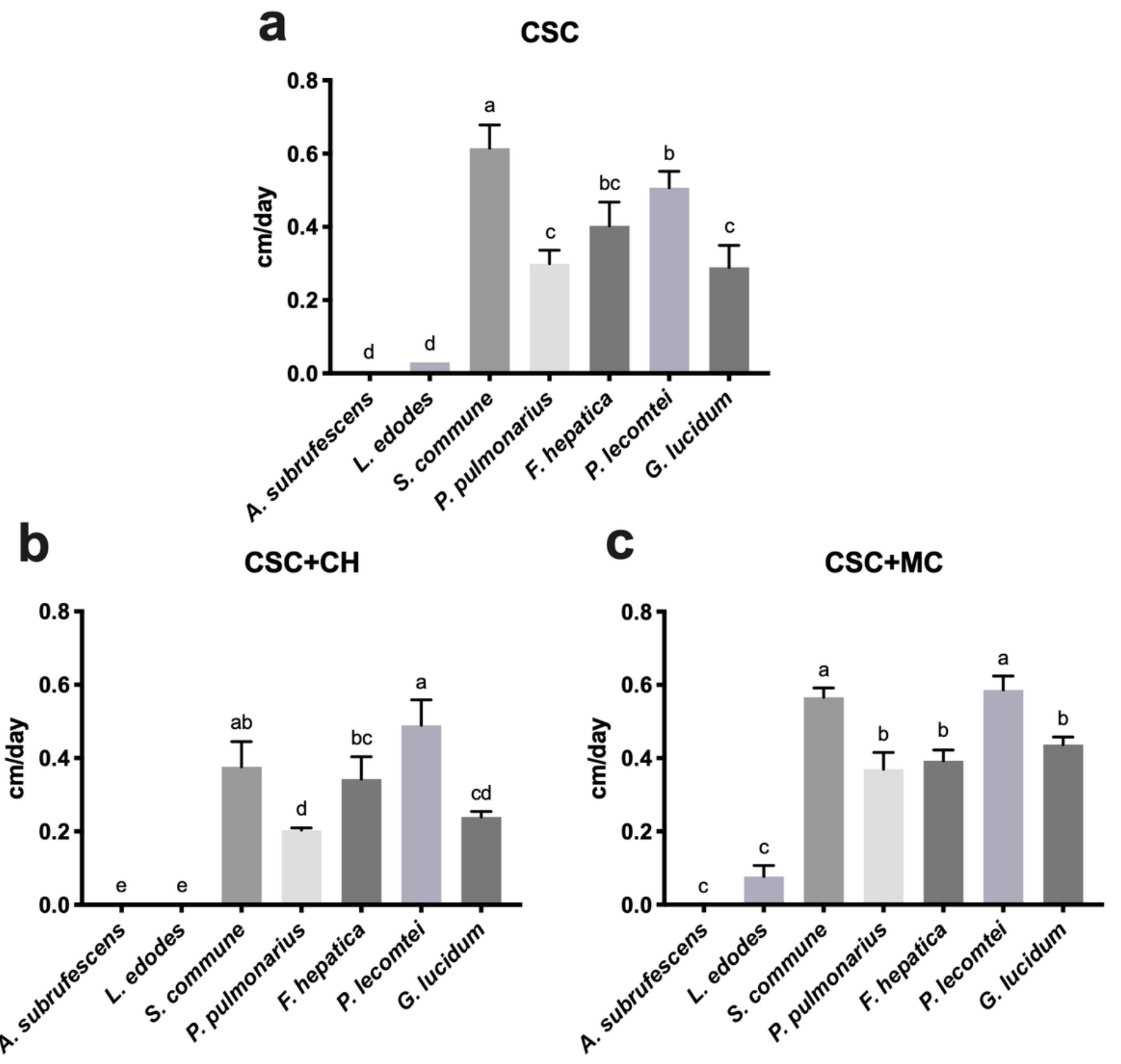

Figure 2

Growth rate (cm/day) of seven basidiomycetes colonized in cottonseed cake, cottonseed cake with coconut husks and cottonseed cake with macauba cake during 15 days in $10 \mathrm{~cm}$ jars. CSC: Cottonseed cake; $\mathrm{CH}$ : Coconut husks; MC: Macauba cake. Means followed by the same letter are not different by Tukey test $(p<0,05)$.

\section{Supplementary Files}


This is a list of supplementary files associated with this preprint. Click to download.

- floatimage1.jpeg 